\title{
The recent slowdown in bank lending in Spain: are supply-side factors relevant?
}

\author{
Ignacio Hernando • Ernesto Villanueva
}

Received: 30 May 2013 / Accepted: 28 July 2014 / Published online: 15 August 2014 (C) The Author(s) 2014. This article is published with open access at SpringerLink.com

\begin{abstract}
Using information from the balance sheets of Spanish banks between 1995 and 2009 matched to credit information at the bank-industry and bank-firm level, we estimate the average impact of current and anticipated changes in banks' capital on lending to firms. We isolate the role of credit supply factors using the variation in capital growth associated with the bank-specific historical exposure to real estate development and its interaction with the change in house prices in the provinces where the banks operate. We control for the quality of borrowers by using region and industry fixed effects. A $1 \%$ increase in capital growth increases business lending to non-real estate firms by between 0.7 and $0.8 \%$ - a limited magnitude when set against the literature. The relatively small magnitude of credit supply factors may be explained by the weakness of loan demand in a context of deep recession.
\end{abstract}

Keywords Bank lending $\cdot$ Bank capital $\cdot$ Loan supply $\cdot$ Instrumental variables

JEL Classification $\quad \mathrm{E} 51 \cdot \mathrm{G} 21$

\footnotetext{
We thank the Editor and two anonymous referees whose comments helped us considerably. Francisco Alonso, Carlos Sierra and Ignacio Fuentes provided help with the database. We also thank the comments of Ugo Albertazzi, Juan Ayuso, Roberto Blanco, Leonardo Gambacorta, Ángel Gavilán, Jonatan Groba, Victoria Ivashina, Juan Francisco Jimeno, David Marqués, Jorge Martínez Pagés, José Luis Peydró, Carlos Pérez-Montes, Javier Suárez, and the participants at the Desenvolvimento Economico Portugues Conference, the 2012 ESEM Day-Ahead Conference, the May 2010 meeting of the Eurosystem's Working Group on Econometric Modelling, at the XIX Finance Forum in Granada and a Banco de España seminar. The views expressed in this paper are those of the authors and do not necessarily reflect those of the Banco de España.
}

I. Hernando · E. Villanueva $(\varangle)$

Banco de España, Madrid, Spain

e-mail: ernesto.villanueva@bde.es 


\section{Introduction}

The role of bank balance sheets in shaping credit growth received substantial attention during the 2008 recession. On the one hand, exposure to "toxic" assets affected some banks' ability to lend (see Puri et al. 2011). On the other hand, even in banking systems without structured off-balance sheet products, but with a high exposure to real estate, drops in house prices have impaired financial intermediaries' capital positions and, possibly, the overall supply of credit. This paper analyses the case of Spain, an economy that experienced a housing boom until 2007 and a drop in business lending in 2009, to gauge the impact of (current and anticipated) changes in bank capital on business lending. ${ }^{1}$

The Spanish financial system was not severely hit by the first wave of the global financial crisis, as a result of a number of factors: the negligible presence of toxic assets on bank balance sheets; regulations that prevented the creation of off-balance sheet investment vehicles; and the large weight of long-term instruments in their funding structure. However, as the initial financial turmoil turned into a deep recession, Spanish banks were increasingly affected as their high exposure to the real estate sector and the sharp increase in unemployment led to a major deterioration in the quality of their loan portfolios. The existence of provisioning buffers required by the Spanish prudential regulatory system initially mitigated the impact on profits of the surge in non-performing loans. Nevertheless, the progressive reduction in these buffers together with increases in the target capital ratios considered acceptable by regulators and markets have put additional pressure on banks' capital. All these developments may have constrained the credit supply of some institutions.

Disentangling the specific contribution of bank capital from demand-related factors is a difficult task. In a time series context, firms revise downward their investment plans and, consequently, their demand for loans. At the same time, bank capital and borrower creditworthiness deteriorate in a recession, so stricter lending standards are applied by financial institutions. Alternatively, in a cross-section context, banks and firms do not match randomly and it may be the case that firms whose demand for credit is most sensitive to recessions end up borrowing from the smallest and least capitalized banks.

Our strategy is the following. Firstly, guided by a simple model of bank behavior that predicts that lending growth is conditioned by capital growth only when the level of capital is near the amount required either by the regulator or the funding markets, we study two different channels through which the capital position of a bank may affect its lending behavior (see Van den Heuvel 2001). The first relates changes in lending to firms to current changes in the capital position of a bank. The second is highlighted in the literature on bank lending under uncertainty and captures cuts in lending associated with anticipated future reductions in capital stemming from expected losses.

Secondly, to identify the role of supply factors in business lending, we use financial statements (balance sheets and profit and loss accounts) reported by the Spanish depository institutions to the supervisor between 1995 and 2010. We match this information

1 For instance, Puri et al. (2011) show that German regional banks that were more exposed to subprime lending in the US were more likely to reject applications of consumer and mortgage loans. Our paper focuses on business loans. 
to data on business lending at the bank-industry level and, as a robustness check, to data at the bank-loan level. We then use an instrumental variable procedure along with industry-year and firm-year fixed effects to address the simultaneity between lending and capital. Our instrument is based on Watanabe (2007) and relies on bank-specific exposure to real estate development as of 1995. The underlying idea is that, unlike banks that enter the real estate development industry during a housing boom, banks with a traditionally high exposure to real estate development are likely to better know the industry than the rest, but possibly due to relationship lending, they are more likely to be exposed to the ups and downs of real estate prices. That fact, combined with whether or not these banks operate in areas that experienced house price declines, permits us to track the changes in banks' capital position for reasons unlikely to be related to the quality of firms' demand for loans as of 2007.

Our findings can be summarized as follows. Firstly, lagged exposure to real estate development and its interaction with local house prices in the provinces where banks operate are good predictors of capital growth only after 2008, when house prices had accumulated two years of negative growth at the national level. Secondly, those same instruments predict changes in the overall non-performing loans (NPL) ratio already in 2008. We find that the exposure to real estate and its interaction with house prices predicts the NPL ratio only in the real estate development sector and for banks that operated in provinces where housing prices fell. Finally, we find that banks that were more exposed to real estate developers cut their lending to a larger extent during the recession, and that the drop in business lending was mitigated if the banks operated in provinces where house prices fell less. These results hold in analyses performed at matched bank-industry level, but also in specifications using matched bank-loan data that control for the quality of the borrower by means of firm-year fixed effects. Interestingly, using firm level data, we find rather similar cuts in lending across all firms, independently of their size.

Finally, we estimate two stage least squares (TSLS) models of credit growth on current and (proxies of) anticipated capital growth. We find a statistically significant elasticity of business lending to actual capital growth of about $0.7-0.8$. Nevertheless, back-of-the-envelope calculations suggest a limited role for the capital channel during the sample period we consider (accounting for 18-21\% of the actual credit reduction). Overall, our preferred estimates suggest that the deterioration of banks' capital position has had a negative but limited effect on the supply of loans to firms.

We make three distinct contributions. Firstly, we contribute to the debate on the role of house price dynamics in bank balance sheets and business credit. Gan (2007) finds that Japanese banks that were more exposed to real estate development cut business lending after a sizable fall in aggregate real estate prices. However, Chaney et al. (2012) or Cuñat et al. (2014) advocate the use of local house prices to study balance sheet effects, as aggregate prices may correlate with macro factors such as exchange rates. Chaney et al. (2012) find that shocks to the value of firms' collateral diminish investment while Cuñat et al. (2014) document that banks cut their lending in response to local house price drops. We estimate how local house prices and banks' exposure to real estate development affect capital growth, NPLs and loans granted by banks. We also document that house price increases did not affect capital or business lending growth, but house price reductions actually did. Secondly, we find that house prices 
in the provinces where a bank operates affect business lending even when the prices in the locality where firms operate hold constant. That finding suggests that changes in local house prices spread to other regions through banks' balance sheets.

Secondly, and due to Spanish regulations, the dynamic provisioning system allows us to separate the role of contemporary and anticipated capital growth in determining the changes in business credit. The stylized model we use delivers quantitative predictions on the impact of capital growth on business credit; it should be bounded between zero and one. That is not necessarily the case when anticipated capital growth is not held constant.

Finally, our results cast light on possible reasons for the discrepancies among existing estimates of the role of bank capital in determining business credit. Berrospide and Edge (2010) use aggregate data and find a very limited role for bank capital asset ratios in business lending growth. Using loan level data, Albertazzi and Marchetti (2010) and Jiménez et al. (2012) find larger impacts made by banks' balance sheets. The discrepancy among those results could either be due to cross-country differences in the dependence of firms on bank lending or, alternatively, to differences in the level of data disaggregation. The availability of comprehensive loan-level and of aggregate data allows the response of lending growth to balance sheet shocks to be estimated using data on business loans granted both at the bank-loan and at the bank-industry level. The response of credit growth to banks' exposure to real estate development and its interaction with local house prices does not depend greatly either on the degree of the data aggregation or on whether or not we control for the quality of borrowers by means of firm-year fixed effects. Hence, the heterogeneity in responses across studies may depend more on the extent to which firms depend on banks for their funding or on the nature of the shocks that affect bank balance sheets.

The rest of the paper is organized as follows. The next section contains a brief review of the recent literature analyzing the influence of a bank's capital position on its lending provision. Section 3 describes the theoretical framework and our empirical strategy. Section 4 presents the procedure used to address the potential simultaneity of capital and lending, and describes the data sources and the variables included in the empirical specifications. Section 5 discusses the results obtained while Sect. 6 provides some robustness checks at the bank level. Section 7 examines loan level outcomes. Finally, Sect. 8 offers some concluding remarks.

\section{Bank capital and lending growth: an overview of the empirical literature}

The detailed theoretical model linking bank capital and bank lending operates through capital regulation. This bank capital channel is explicitly modeled by (Van den Heuvel 2001, 2002). Assuming both an imperfect market for bank equity and risk-based capital requirements, he shows that when capital drops to a sufficiently low level, as a result of an increase in loan losses, the bank will reduce lending because of the capital requirement and the cost of issuing new equity. Capital does not necessarily need to fall below the capital requirement to trigger a reduction in lending, as the bank might 
prefer to forgo some lending opportunities in order to reduce the risk of breaching the capital regulatory limit in the future.

On the empirical side, the impact of bank capital on loan growth has been a highly researched area in specific episodes of credit slowdown. In particular, a number of papers explored the role of the introduction of new bank capital regulations (Basel I) in explaining the credit slowdown in the early 1990s in the US economy. These studies did not provide a conclusive answer on the potential existence of a bankcapital-induced credit crunch. Bernanke and Lown (1991), using a cross-section of year on year growth rates for 1991:Q1 found that actual capital-to-asset ratios had a significant effect on loan growth, although the relevance of this effect was significantly lower than that of economic activity. Berger and Udell (1994) did not find a significant effect of alternative definitions of capital ratios on loan growth during the period 19901992. By contrast, Hancock and Wilcox (1993) found, for a sample of US banks in 1990, that shortfalls in capital ratios (measured in relative terms to a target level) had a significant effect on loan growth.

Using an alternative approach and a sample of banks in New England over the period 1989:Q2 to 1994:Q4, Peek and Rosengreen (1995) found that capital growth was the main determinant of lending growth for a sample of banks with low regulatory ratings (and hence presumably constrained), whereas it did not have a significant effect for the a priori unconstrained banks. Given the large number of banks with low regulatory ratings in New England in the early 1990s, these authors argue that capital constraints may have played an important role in the sluggish lending growth and weak economic activity at that time. Their estimates suggest that a $1 \%$ point increase in capital growth raised the supply of credit (among low regulatory ratings banks) by $5 \%$ points. We discuss below that the magnitude of that impact is very large.

Several papers have analyzed whether or not the weakness of lending growth might be related to the demand by the Japanese regulator for a rigorous self-assessment of their assets, which led to a substantial amount of loan loss write-offs and provisions. Focusing on that later development, Woo (2003) and Watanabe (2007) found that Japanese banks significantly reduced their lending in response to a large increase in bank capital requirements resulting from the reinforcement of the prudential policy guidelines by the Japanese regulator. Watanabe's results suggest a very large role was played by the contraction of capital in business lending: had capital not been squeezed, business lending to sound industries (which indeed fell, depending on the industry, between 3 and $5 \%$ points) would actually have increased. Instead of looking at regulatory changes, we analyze the impact of changes in bank capital associated to changes in house prices at the onset of a (severe) recession.

The magnitude of the current financial crisis has renewed the interest in this literature. Some recent papers have shed some light on the relevance of the effect of bank capital on lending growth during the current crisis. However, their results are far from being conclusive, mostly because the crisis or, at least, its effects on bank balancesheets, were still under way. Using a sample of US bank holding companies over the period 1992:Q1 to 2008:Q3, Berrospide and Edge (2010) find small effects of capital surpluses/shortfalls on lending. Larger effects are found by Francis and Osborne (2009) using a sample of U.K. banks over the period 1996:Q2 to 2007:Q4 and a similar methodology to that in Berrospide and Edge (a panel regression of loan growth on the 
deviation of bank capital with respect to a target). Albertazzi and Marchetti (2010) use highly detailed data on bank-firm relationships (compiled by the credit register of the Banca d'Italia) and find that those banks with poor capitalization displayed a higher contraction in bank lending over the period from September 2008 (just after the collapse of Lehman Brothers) to March 2009. Jiménez et al. (2012) estimate large impacts of monetary shocks on loan granting decisions of bank with relatively low capital asset and liquidity ratios. Among other factors, the discrepancies among those results could be due to differences in the level of disaggregation of the data (loan level data vs bank balance sheets) or to the nature of the shocks considered in each paper. Our study conducts the analysis at several levels of disaggregation to cast light on the role of those components.

\section{The link between bank's capital and lending to firms}

Most of the empirical work that assesses the role of supply factors in explaining lending developments uses a reduced form relationship between loan growth and a capital ratio. In addition, some studies, like Watanabe (2007) or Berrospide and Edge (2010) attempt to measure banks' capital surplus, i.e. the difference between the observed and the desired capital ratios. By contrast, in theoretical models of corporate finance, decisions are usually modeled in terms of capital levels rather than in terms of capital-asset ratios. We use a simple model of bank behavior to derive a relationship between the growth rate of lending and the growth rate of capital that does not require measuring an exact measure of the bank's capital surplus.

\subsection{A simple model of bank behavior}

We use a multi-period stylized model of bank behavior based on Van den Heuvel (2001) — see Appendix 1 for the details. The bank holds only loans $\left(L_{t}\right)$, and has two types of liabilities, capital $\left(K_{t}\right)$ and deposits $\left(D_{t}\right)$. The bank also faces an inelastic demand for deposits at a given rate $r_{D}$ and chooses its level of capital and loans, while its yearly profits can be written as follows:

$$
\pi_{t}=\left[R\left(L_{t}\right) L_{t}-r_{D} D_{t}\right]
$$

The capital of a bank $K_{t}$ evolves as follows:

$$
K_{t}=K_{t-1}+(1-\tau) \pi_{t}-d_{t}
$$

where $\tau$ is the corporate tax- and $d_{t}$ is a dividend. The constraint implies that banks can only increase capital through retained post-tax profits $\pi_{t}(1-\tau)$. In addition, banking regulations require banks to have a minimum level of capital that depends on the total outstanding credit amount $L_{t}$

$$
K_{t} \geq \gamma^{R} L_{t}
$$


We assume that whenever capital falls below its regulatory minimum $\gamma^{R}$, banks are not allowed to extend new loans or to pay dividends, thus forgoing profitable lending opportunities. The bank maximizes the discounted stream of future dividends subject to the evolution of capital and to the capital regulatory constraint.

Several reasons lead lending institutions to hold a capital level that exceeds the time invariant capital asset ratio $\gamma^{R}$. Firstly, Spanish supervisory authorities require banks to keep an extra layer of capital associated to "dynamic provisioning", described in Sect. 3.2.1. Even in such a simple setting, minimum capital requirements consist of a time invariant component $\gamma^{R}$ and of a time-varying counter-cyclical buffer capturing dynamic provisioning - that we term $\gamma_{t}^{U}$. Secondly, banks may have their own assessment of the distribution of future losses and may keep an extra layer of reserves as Tier 1 capital. ${ }^{2}$ Finally, financial markets condition their lending upon certain characteristics of the borrowing bank, such as its capital-asset ratio. ${ }^{3}$ Those considerations lead us to model the magnitude capital buffer $\gamma_{t}^{U}$ as a function of expected losses as well as on the cost of deposits $r_{D}$. The level of capital $K_{t}$ must then exceed that implied by the capital-asset ratio required by the regulator $\left(\gamma^{R} L_{t}\right)$ by an additional, possibly time varying, ratio $\left(\gamma_{t}^{U} L_{t}\right){ }^{4}$

$$
K_{t} \geq\left(\gamma^{R}+\gamma_{t}^{U}\right) L_{t}
$$

We note three results

Result 1 When the capital constraint is binding and the desired amount $L_{t}^{*}$ is such that $K_{t}<\left(\gamma^{R}+\gamma_{t}^{U}\right) L_{t}^{*}$, lending growth is equal to the growth of bank's capital

$$
\Delta \log L_{t}=\Delta \log \frac{1}{\gamma^{R}+\gamma_{t}^{U}}+\Delta \log K_{t}
$$

That is, if we were able to identify which banks face a capital constraint in the data, and used that sample of constrained banks to run a cross-sectional regression of $\Delta \log L_{t}$ on $\Delta \log \frac{1}{\gamma^{R}+\gamma_{t}^{U}}$ and $\Delta \log K_{t}$, the coefficient of the latter variable would be one. That is, among capital constrained banks, loan growth equals capital growth.

Result 2 If $K_{t} \geq\left(\gamma^{R}+\gamma_{t}^{U}\right) L_{t}^{*}$, lending growth reflects the growth in the marginal benefit from lending relative to the marginal cost of funds. Neither of those magnitudes depends on capital growth. Assuming again that we were able to identify which banks do not face any capital constraint, a cross-sectional regression of $\Delta \log L_{t}$ on $\Delta \log \frac{1}{\gamma^{R}+\gamma_{t}^{U}}$ and $\Delta \log K_{t}$ ran in that sample would deliver a zero coefficient of $\Delta \log K_{t}$.

\footnotetext{
2 Van den Heuvel's model is similar to the one above, but there banks are uncertain about the cost of their own borrowing and about the distribution of future losses. In his model banks accumulate extra capital to insure against the risk of being capital constrained in the future.

3 However, we note that reserves due to dynamic provisioning belong to Tier 2 capital, while the empirical analysis uses Tier 1 capital.

4 The empirical application models the current share of non-performing loans (NPLs) as a main component of $\gamma_{t}^{U}$, in turn, a predictor of future losses and of future negative additions to capital.
} 
Result 3 The coefficient of $\Delta \log K_{t}$ in a cross-sectional regression of $\Delta \log L_{t}$ on $\Delta \log \frac{1}{\gamma^{R}+\gamma_{t}^{U}}$ and $\Delta \log K_{t}$ must be bounded between 0 and 1 . The coefficient would be zero if no bank faced a capital constraint and one if all banks faced such constraint. Peek and Rosengreen (1995) use a cross-section of banks and show that capital growth affects business lending only because current capital falls between the legal minimum and the desired level of capital for a fraction of banks. Our strategy builds on that result, but places bounds on the coefficient of $\Delta \log K_{t}$.

Note that banks with capital levels above the regulatory minimum may cut lending because of an anticipation effect or because of changes in capital requirements by financial markets. In either case, banks anticipate future capital needs and thus target a lower ratio of business lending to capital. The coefficient of the variable $\Delta \log \frac{1}{\gamma^{R}+\gamma_{t}^{U}}$ identifies that response. In addition, by regressing $\Delta \log L_{t}$ on $\Delta \log \frac{1}{\gamma^{R}+\gamma_{t}^{U}}$ and on $\Delta \log K_{t}$ we abstract from the difficult problem of estimating a bank specific target capital, because such a term is left implicit in $\Delta \log \frac{1}{\gamma^{R}+\gamma_{t}^{U}}$. Watanabe (2007) or Berrospide and Edge (2010) highlight the difficulties inherent in estimating target capital levels.

\subsection{Empirical implementation and identification strategy}

We work with year-specific regressions of business lending growth on capital growth and changes in the share of non-performing loans between 2004 and 2010. The main unit of analysis is the bank-industry cell, but we also experiment with matched bankfirm data in a separate analysis. Namely, we implement the following version of (1)

$$
\Delta \log L_{t}=\beta_{1} \Delta \log \left(\gamma^{R}\right)+\beta_{1} \Delta \log \left(\gamma_{t}^{U}\right)+\beta_{2} \Delta \log K_{t}+\varepsilon_{t}
$$

$\beta_{1}$ multiplies the first two terms as both enter additively in (1). Result 3 above shows that Eq. (2) is an average of the responses of capital-constrained banks (for whom $\beta_{1}$ and $\beta_{2}$ are both equal to 1 ) and capital unconstrained banks (for which both coefficients are zero). $\beta_{2}$ measures the sensitivity of loan growth to capital growth and, as discussed above, it must lie between zero and one.

\subsubsection{Proxies for $\Delta \log \left(\gamma_{t}^{U}\right)$}

We treat $\Delta \log \left(\gamma^{R}\right)$ as a constant because the regulatory capital-to-asset ratio did not change during the sample period. However, $\Delta \log \left(\gamma_{t}^{U}\right)$ - the capital buffer that a bank holds in excess of the regulatory minimum - is a relevant, unobserved regressor. We model $\gamma_{t}^{U}$ as a year-specific function of expected future losses (that we identify with the share of non-performing loans) and of the lagged capital asset ratio (that determines the market's perception of the situation of the bank and, in turn, the cost of borrowing).

$$
\Delta \log \left(\gamma_{t}^{U}\right)=\delta_{0}+\delta_{1} \Delta N P L_{t}+\delta_{2} \frac{K_{t}}{L_{t}}+u_{t}
$$


The dependence of $\gamma_{t}^{U}$ on $\Delta N P L_{t}$ is due to regulatory reasons. In 2000, the Banco de España set up a system of "dynamic provisioning". According to that regulation, in expansionary periods when the share of NPLs falls below an historical average banks are required to set aside a class of general-purpose loan provisions (i.e., provisions against a loan default that has not occurred yet). Conversely, when the share of NPLs is above an historical average - typically, during a recession-banks may set aside a lower level of general-purpose provisions. ${ }^{5}$ At the beginning of a recession, the ratio of non-performing loans typically increases, but that change is compensated by a lower need to set aside general-purpose provisions. Hence, an increase in the share of NPLs will not instantaneously reduce profits or capital growth. ${ }^{6}$ The system of dynamic provisioning implies that the effect on lending of sharp increases in the share of NPLs-like those observed in the period we analyze-are conceptually distinct from current changes in capital. The distinction allows us to distinguish between anticipatory and pure capital growth effects.

We assume that $\gamma_{t}^{U}$ also depends on the (lagged) capital-asset ratio $\frac{K_{t}}{L_{t}}$. Thus far, we have abstracted from differences across banks in the cost of raising funds. Yet, banks with a higher volume of capital may be able to obtain lower financing rates in the funding markets. In such a case, capital growth would also be positively related with loan growth among unconstrained banks. ${ }^{7}$ We account then for differences in the cost of raising funds by including the capital asset ratio its asset size, both measured as of 1995 .

\subsubsection{Identification}

Capital growth and loan growth are simultaneously determined over the business cycle. In an economic downturn the quality of the demand for loans falls (reflecting weaker activity) and the capital of banks diminishes as well (as a result of an increase in non-performing loans). To estimate causal, separate effects of capital growth and of changes in $\frac{1}{\gamma^{R}+\gamma_{t}^{U}}$ on loan growth, we use an instrumental variable procedure. A valid instrument must be correlated with the growth of capital while uncorrelated with the quality of borrowers in 2009.

5 The formula that governs the evolution of those general-purpose provisions, or provisions against unrealized losses is

$$
P_{t}=P_{t-1}+\rho\left[N P L_{t}^{e}-N P L_{t}\right]+\left[N P L_{t}^{e}-N P L_{t-1}^{e}\right]
$$

$P_{t}$ represents the euro amount of general-purpose provisions (as opposed to loan-specific ones) that the bank must set aside in period $t . N P L_{t}$ is the actual losses due to loans that were not repaid during period $t$. $N P L_{t}^{e}$ represents a smooth function of expected losses through the business cycle. $\rho$ is a parameter between zero and one that depends on the type of loan.

The working assumption is that in a period when $N P L_{t}^{e}>N P L_{t}$, realized losses are below average, so the overall portfolio of loans must contain a fraction of loans that will default in the future. Those latent losses justify extra provisioning when $N P L_{t}$ is below average. The converse happens when $N P L_{t}^{e}<N P L_{t}$.

6 However, such losses anticipate capital needs in the future if the increase in the share of NPLs is persistent.

7 Peek and Rosengreen (1995) explicit incorporate heterogeneity in the cost of raising funds in their theoretical framework. They show that the response of loan growth to capital growth is larger among constrained banks than among unconstrained banks. 
The dynamics of capital accumulation suggests that any shock that increases the share of non-performing loans is likely to affect capital growth. As shown in Table 1, the Spanish banking system was very exposed to real estate development as of 2007, with $30 \%$ of business loans being granted to that sector. In such a setting, changes in the price of real estate are likely to affect the share of NPLs and, subsequently, capital growth. Based on those considerations, we exploit the variation in lagged exposure to real estate development and its interaction with the change in house prices to identify movements in capital and growth in the share of NPLs.

Our identification strategy builds on the approach used by Watanabe (2007), who also examines the link between bank's capital and loan growth in the second half of the 1990s. Watanabe uses the individual bank's share of lending to the real estate industry in 1989 as an instrument for that bank's capital to asset ratio in the late 1990s, as we do. ${ }^{8}$ However, and unlike Watanabe, we control for anticipated falls in capital growth and use the wide variation associated to changes in local house prices.

We instrument $\triangle N P L_{t}$ and $\Delta \log K_{t}$ using variation in bank's industrial specialization 13 years before the crisis and shortly before the beginning of the housing boom in the late nineties. Our identifying hypothesis is that specialization in a sector generates persistence due to informational advantages. Banks that were more specialized in borrowing to real estate developers before the construction boom were in a better position to take advantage of the increasing demand of activity in that sector because of their expertise. Indeed, Fig. 1 shows that those banks that were comparatively more exposed to real estate development in 1995 ended up with a higher exposure when the slowdown started in $2007 .{ }^{9}$ In addition, specialization in real estate development in 1995-1997 is unlikely to be correlated with demand quality in industries other than construction in 2007. We provide evidence below in support of that identifying assumption.

\section{Instrumenting non-performing loans}

We instrument the share of non-performing loans using the fact that the profitability of the real estate development sector is closely linked to the evolution of house prices. In particular, falls in local house prices are a likely driver of losses of banks that were initially exposed to real estate development. Thus, we also use as an instrument for $\triangle N P L_{t}$ the interaction between the bank's exposure to real estate developers at the beginning of the boom and the average change in house prices in the years previous to the bust in the provinces where the bank operates (weighted by the number of branches in such provinces). As we also control for regional fixed effects, such interaction captures the drop in loan profitability within a province that is due to a bank's specialization in real estate development at the onset of the housing boom.

\footnotetext{
8 The underlying rationale for such instrument is similar to ours: Japanese banks substantially expanded their lending to the real estate industry during the 1980 s as a result of regulatory changes and those banks that showed a higher shift towards this sector experienced a sharper increase in their non performing loans ratios and a deep weakening in their capital positions ten years later when housing prices started to fall and regulatory reforms required banks to accordingly revaluate unrealized losses.

9 Admittedly some of the institutions that dramatically expanded their lending to the real estate development sector over the boom years were not highly exposed to this sector at the end of the past decade. Such "latecomers" may well have suffered heavy losses and cut their lending between 2008:Q4 and 2009:Q4. However, it can also be argued that those lending institutions were picking up the borrowers with the highest chance of defaulting.
} 


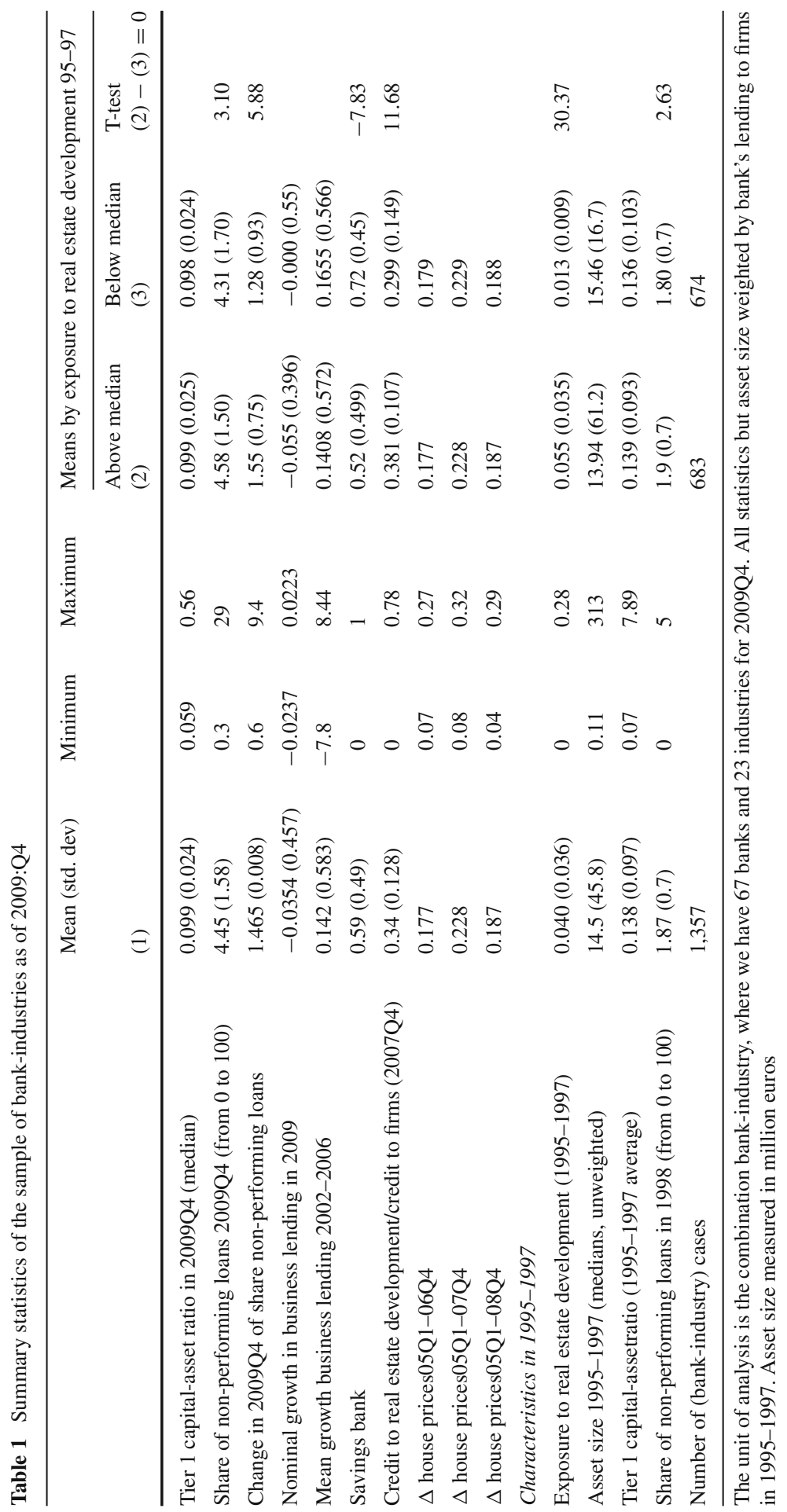




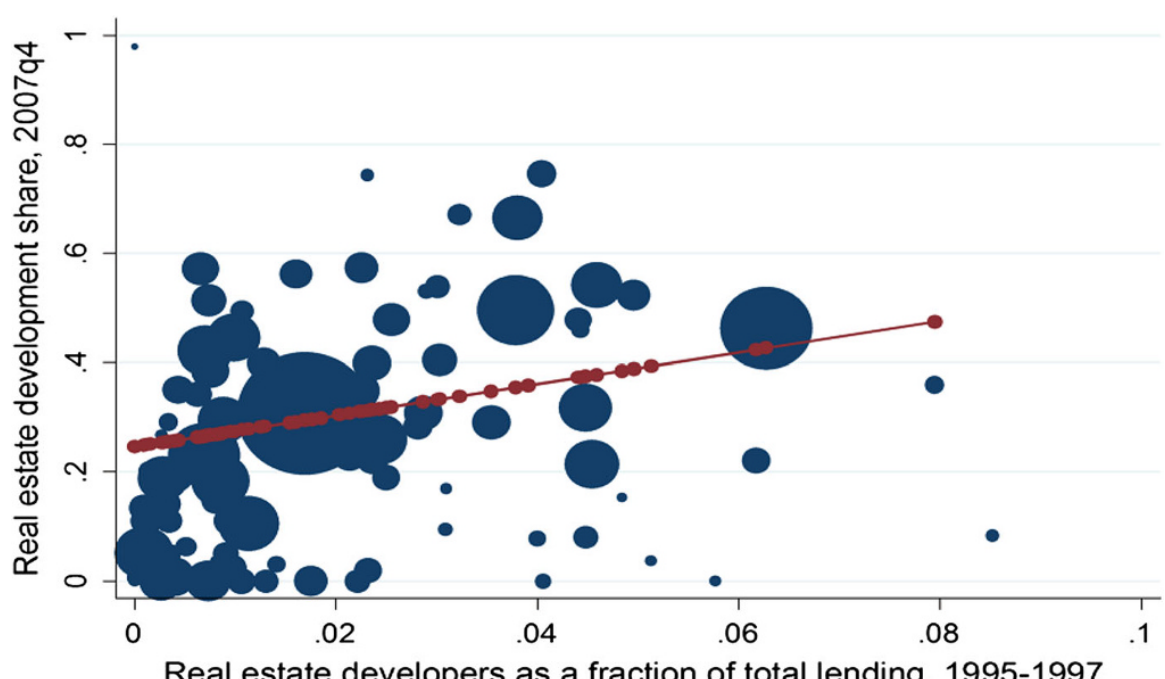

Fig. 1 The relationship between the weight of real estate development in 1995-1997 and the weight of the same industry in 2007Q4. Each dot represents a combination of the share of credit to real estate developers in business lending between 1995 and 1997 and that same share in 2007q4. Each dot is weighted by the average of total assets between 1995 and 1997

The two first stages (for capital growth and the change in non-performing loans) take the following form

$$
\begin{aligned}
\Delta K_{t} & =\eta_{0}+\eta_{1} \operatorname{Exp} \underset{95-97}{\mathrm{real}}+\eta_{2} \operatorname{Exp} \underset{95-97}{\operatorname{real}} \Delta H P R I C E_{t}+u_{t} \\
\Delta N P L_{t} & =\theta_{0}+\theta_{1} \operatorname{Exp} \underset{95-97}{\mathrm{real}}+\theta_{2} \operatorname{Exp} \underset{95-97}{\mathrm{real}} \Delta H P R I C E_{t}+u_{t}
\end{aligned}
$$

Note that Exp real95-97 $\triangle H P R I C E_{t}$ may well affect $\triangle N P L_{t}$ but is unlikely to affect $\Delta \log K_{t}$. The reason is that at the beginning of a recession banks must have accumulated reserves through dynamic provisioning, as discussed above. As a result, recent losses will not be immediately transmitted into a lower capital growth. We test below if Exp real95-97 $\triangle H P R I C E_{t}$ affects capital growth-and find it does not. That feature of the Spanish banking regulation is crucial to identify the separate impacts of $\triangle N P L_{t}$ and $\Delta \log K_{t}$ on loans to non financial corporations.

\section{Data and empirical specification}

\subsection{Data}

\subsubsection{Bank statements}

The first sample used in this paper comes from the bank statements (balance-sheets, profit and loss accounts) reported to the Banco de Españ a by all commercial banks and savings banks between 1995 and 2009. We use the year 2010 in some specifications, 
but not in the main analysis because the number of banks was substantially reduced after 2009. This information is available with (at least) a quarterly frequency at the bank level. The bank balance sheets contain the stock of outstanding lending to firms grouped in 23 different industries and, for each industry, we also know the share of non-performing loans up to 2009:Q1. The information on capital requirements is only available for the whole sample at a yearly frequency and on a consolidated basis. We use Tier 1 capital, which includes capital, disclosed reserves, preference shares and nonvoting equity.

Our main analysis takes as the sample unit the pair bank-industry. For example, a bank that has outstanding loans with firms in all 23 industries contributes 23 cases to the sample. Organizing the sample this way, we are able to control for the industry specialization of banks using industry fixed effects. The summary statistics are shown in Table 1. Our sample of domestic commercial and saving banks contain 1,357 bank-industry observations corresponding to 67 lending institutions that in 2009Q4 accounted for $77.8 \%$ of total loans granted by depository institutions, $82.5 \%$ of total deposits and $83.7 \%$ of total assets. In turn, those 67 banks belong to 55 groups that present consolidated balances yearly. ${ }^{10}$

\subsubsection{Loan level information}

Banks and firms do not match randomly, raising the concern that the link between bank's capital and loan growth reflect changes in the (unobserved) determinants of the firm's demand for credit, rather than bank's balance sheet effects. Khwaja and Mian (2008) or Jiménez et al. (2012) propose holding the (unobservable) quality of a firm constant by means of firm-year fixed effects using matched data of banks and firms. As a robustness check, we redo the analysis using loan-level data from the credit register of Banco de España (BdE). In its supervisory role, BdE receives from lending institutions a monthly report about outstanding loan amounts above 6,000 euro, each classified by its type of collateral and repayment status. The version of the data we use contains no other firm-level information, although we obtained information about the industry of the firm as of December 2009.

We construct the loan-level sample in such a manner that each cell contains the outstanding amount of all loans (granted and available) by bank $i$ to firm $f$ in period $t$. In addition, drawing on the information about the industry of the borrower in 2009 , we exclude loans to other financial institutions or to the public administration. The sample contains 1,413,531 loans from 67 institutions.

The replication of the study at the loan and industry level has value per se. Unlike balance sheet statements, loan level data are non-existent in many countries-see Berrospide and Edge, 2010. By conducting the analysis at both levels, we illustrate the possible biases (if any) that researchers may incur when using data aggregated at the bank-industry level. To our knowledge, such analysis has not been conducted before and cast lights on the sources of differences among previous studies.

10 We have excluded bank-quarter data when credit shares in the balance-sheet are below $10 \%$ in order to drop institutions that are not relevant for the purpose of this study. We have also excluded two savings banks whose management was taken over by the supervisor. 


\subsubsection{Provincial house prices}

House prices are obtained from the series elaborated between 2005:Q1 and 2008:Q4 by the Ministry of Development (Ministerio de Fomento). The data consists on assessments of the market value of a house made by private companies typically prior to a mortgage concession. The Ministerio constructs the series for the main city in each of the 50 Spanish provinces. ${ }^{11}$ We use the cumulative provincial house price growth between the beginning of the series in 2005:Q1 and the last quarter prior to the year when we analyze lending behavior. Aggregate house prices started falling in nominal terms in early 2008, but in some provinces there were drops already in 2007. By using differences between 2005 and 2008 we make sure that early falls in house prices are included in our measures. We experiment using one year house price changes as a proxy for $\triangle H P R I C E_{t}$ in a footnote below. Table 1 shows the extent of price drops in 2008 in our sample.

\subsection{Empirical specification}

In line with the discussion in Sect. 3, we estimate the separate impact on business lending growth of two different variables: the change in capital and the change in the ratio of non-performing loans. The specification is given by the following system of equations:

$$
\begin{aligned}
& \Delta \log L_{i, t}^{J}=\beta_{0}+\beta_{1} \Delta N P L_{i, t}+\beta_{2} \Delta \log K_{i, t}+\sum_{j=0}^{J} d_{j, t} 1\left(\text { industr }_{j}=j\right) \\
& +\sum_{r=1}^{R} d_{r} 1\left(\operatorname{Region}_{i}=r\right)+d_{s} X_{i, t}+\varepsilon_{i, t}^{j} \\
& \Delta \log K_{i, t}=\alpha_{0}+\alpha_{1} \operatorname{Exp} \underset{95-97}{\operatorname{real}}+\alpha_{2} \operatorname{Exp} \underset{95-97}{\operatorname{real}} \Delta H P R I C E_{i, t-1} \\
& \left.+\alpha_{3} \Delta H P R I C E_{i, t-1}+\sum_{r=1}^{R} d_{r} 1 \text { (region }_{i}\right)+d_{s} X_{i, t}+u_{i, t}^{1} \\
& \Delta N P L_{i, t}=\delta_{0}+\delta_{1} \operatorname{Exp} \underset{95-97}{\mathrm{real}}+\delta_{2} \operatorname{Exp} \underset{95-97}{\operatorname{real}} \Delta H P R I C E_{i, t-1} \\
& +\delta_{3} \Delta \text { HPRICE } E_{i, t-1}+\sum_{r=1}^{R} d_{r} 1\left(\text { region }_{i}\right)+d_{s} X_{i, t}+u_{i, t}^{2}
\end{aligned}
$$

where $L_{i, t}^{J}$ is the amount of loans granted by bank $i$ to industry $j$ at time $t, K_{i, t}$ is the volume of Tier 1 capital of bank $i$ at time $t, \Delta N P L_{i, t}$ is the change in the ratio of non-performing loans, and industr ${ }_{j}$, region $_{i}$ are dummy variables indicating the industry the loan was granted to and the region where the bank has most branches as

11 We excludethe autonomous cities of Ceuta and Melilla located in the African continent. 
of 2006:Q3. Exp real95-97 is the bank-specific share of lending to real estate development between 1995 and $1997 .{ }^{12} X_{i, t}$ includes the type of institution, the average bank size as of 1995-1997, the capital asset ratio in 1995-1997 as well as ratio of non-performing loans in 1998.

The coefficients of interest are $\beta_{1}$ and $\beta_{2}$. The first coefficient isolates cuts in lending due to the anticipation of future capital drops. $\beta_{2}$ measures how current changes in the capital position of a bank affect its lending.

Controls related to the demand for loans We also introduce additional covariates to control for demand quality. First, we introduce 22 industry dummies (the omitted category is "trade") that absorb any factor that affected the quality of the industry during the 2008-2009 period. By including industry dummies, $\beta_{1}$ and $\beta_{2}$ are identified by comparing differences in lending granted to the same industry by banks with different capital growth (or a different variation in the share of non-performing loans). Industry dummies control for the fact that banks specialize in industries that behave differently over the business cycle. However our bank-industry sample cannot control for the differences that would arise if, for example, the banks most exposed to real estate development lent to firms whose demand for funds were most sensitive to the business cycle. The industry fixed-effect strategy would identify a loan supply factor that is really a demand factor. In a separate analysis we use loan-level data to examine the robustness of the estimates once we control for the quality of borrowers by means of firm-year dummies.

Secondly, we introduce nine regional dummies (excluded category: Madrid) based on the region where the bank had most of its branches as of 2006:Q3. Such dummies absorb region-specific trends that may affect lending during the sample period.

Bank-specific controls The summary statistics in Table 1 suggest that, relative to the rest of banks, institutions involved in real estate development during 1995-1997 are less likely to be savings banks, had slightly higher capital asset ratios and a higher share of non-performing loans back in 1995-1997. Below, we examine if our estimates vary when we include bank specific variables measured between 1995 and 1997, the period when initial exposure to real estate development is determined. ${ }^{13}$

Models at the consolidated and unconsolidated level Equation (6) is estimated both by (unweighted) OLS and TSLS for the cross-section of banks in the fourth quarter of 2009. As discussed in Sect. 4.1, in the first stage of the TSLS procedure the change in NPLs is regressed on each bank's historical exposure to the real estate development sector (measured by the average of this exposure over the period 1995-

\footnotetext{
12 We identify all the mergers and acquisitions the bank undertook between 1995 and 2008Q4. We then aggregate total outstanding loans to firms and consumers across all banks that result in the same 2008Q4 institution. We do the same for outstanding loans to real estate developers. Exposure to real estate developers is the ratio of the second magnitude relative to the first one. Exp real95-97 is the time series average of that ratio from 1995 through 1997.

13 In particular, the model in the Appendix provides some clues about the role of relevant differences in bank characteristics. Institutions with relatively higher discount rates will deliver a higher stream of dividends and will keep lower level of capital-asset ratios. As not all institutions pay dividends, we proxy for differences in the discount rate by using the bank-specific Tier 1 average capital asset ratio in 1995:Q1-1997:Q4. We also include the average total asset size during the same period as well as the share of non-performing loans to control for differences in attitudes toward risky industries (see Kashyap and Stein 2000 for evidence of differences in lending across banks as a response to monetary policy).
} 
1997). In models (6) and (8) the dependent and key independent variables are defined at the (unconsolidated) bank level-i.e. growth of credit granted or exposure to real estate developers. On the other hand, bank capital requirements are computed at the consolidated level. Equation (7) is thus estimated using the 55 groups that present consolidated balances yearly. The exposure to real estate in that model is also computed at the consolidated group level. For the rest of the covariates in Equation (7) we use the main institution of the consolidated group. The estimated capital loss for the consolidated group is imputed to each of the 67 banks that contribute to the regression with credit growth in the left hand side [that is, model (6)].

\section{Results}

\subsection{The first stage for capital growth}

Table 2 displays the estimates of OLS regressions of the model (4), which has as the dependent variable the growth rate of Tier 1 capital in 2009. This specification uses the sample of 55 consolidated groups. All specifications include regional dummies and the standard errors are corrected for heteroscedasticity. The estimate for the coefficient of the bank's historical exposure to the real estate sector is -0.860 and implies that banks that were $1 \%$ more exposed to real estate development in 1995-1997 experienced a $0.86 \%$ lower growth of Tier 1 capital between 2008:Q4 and 2009:Q4. The F-statistic of the estimate is around 9.94, suggesting a reasonable quality of the instrument.

Interestingly, when we ran a model equivalent to that in the first column of Table 2 using the annualized growth rate of capital between 2004 and 2010 as a dependent variable, the results change significantly. Figure 2 shows that the coefficient of exposure to real estate development in 1995-1997 was basically zero prior to 2009 but turned negative in that year and in 2010. Therefore, the exposure to real estate development between 1995 and 1997 appears to be an adequate instrument for banks' capital growth in 2009 (and 2010).

We also estimated the first stage using not only each bank's historical exposure to the real estate sector but also the interaction of this variable with a measure of the change in house prices between 2005:Q1 and 2008:Q4 as an instrument for each bank's capital growth. Columns $2-4$ of Table 2 display the estimates of this alternative approach using different sets of control variables. The impact of the interaction of real estate development and average provincial house prices on capital growth is very close to zero. A possible explanation is based on the timing of price drops. As already mentioned, the legislation about loan provisioning in Spain makes it unlikely that capital growth reflects recent losses, so changes of local house prices early in 2008 may affect capital growth only after 2009.

\subsection{The first stage for NPL ratios}

The ratio of non-performing loans anticipates the evolution of capital through its impact on profits. We start by examining if the NPL ratio in 2009:Q4 is explained by the bank's historical exposure to real estate development as well as by the interaction 


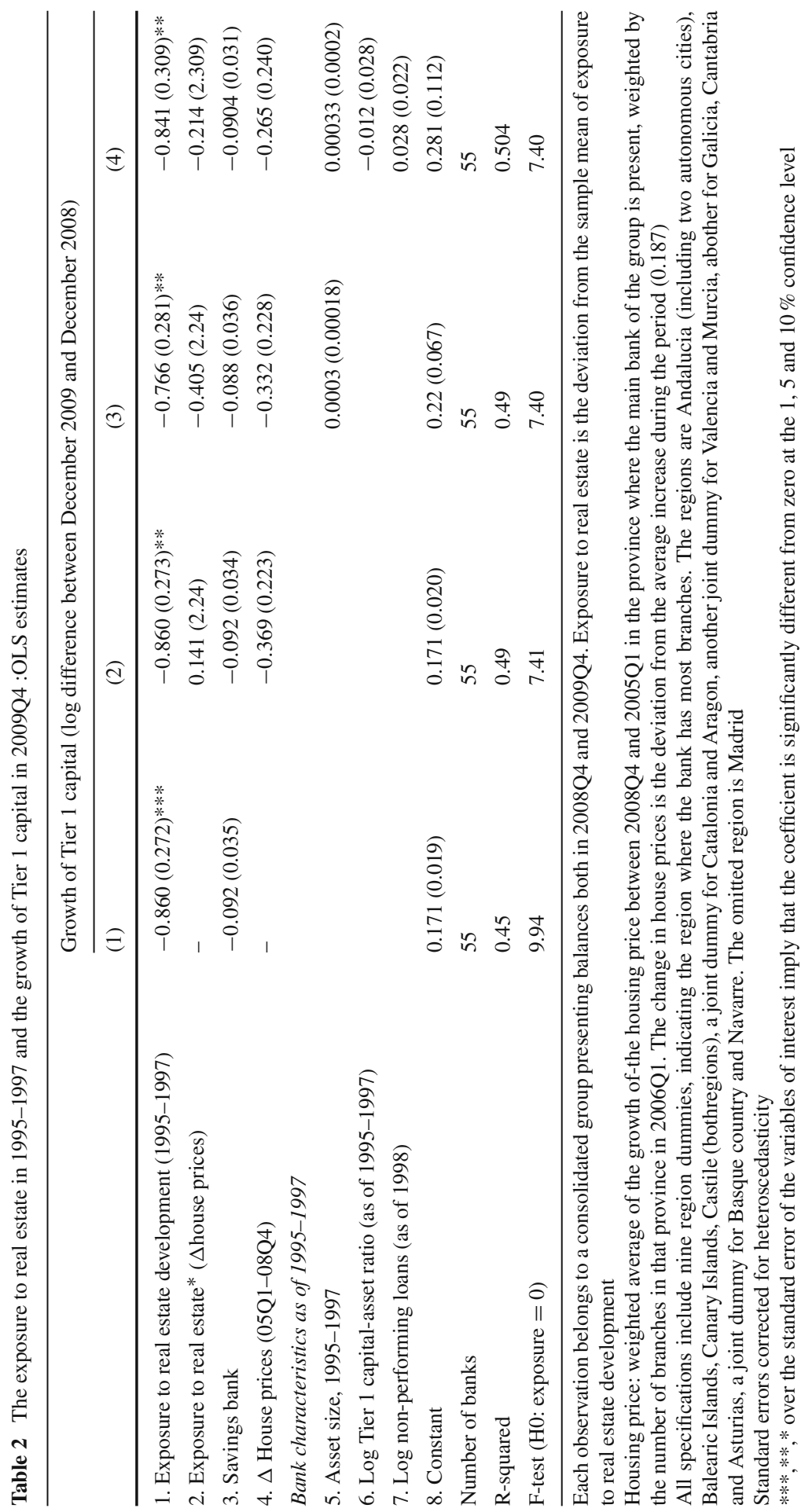




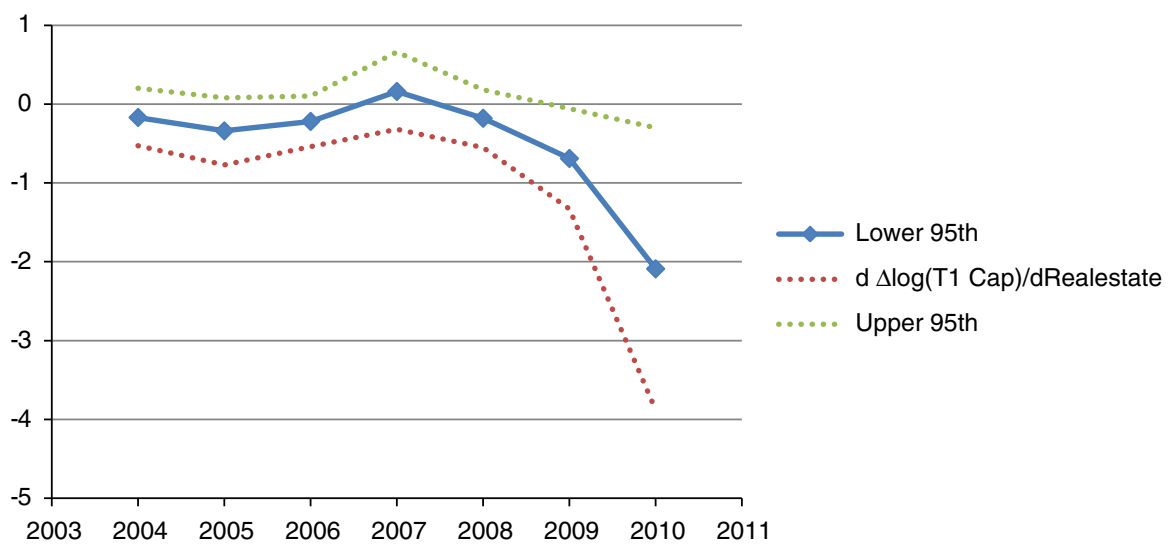

Fig. 2 The impact of exposure to real estate development on tier 1 capital growth, by year. Each dot is the OLS response of tier 1 capital growth to historical exposure to real estate development for each year between 2004 and 2009 Point estimates are obtained from year-specific OLS regressions of tier 1 capital growth on the bank's historical exposure to real estate development (1995-1997), nine region dummies, a dummy for savings bank and total bank assets as of 1995. The dashed lines are the limits of the 95th confidence interval

of that variable with the average cumulative change (between 2005:Q1 and 2008:Q4) of the price of real estate in the provinces where the bank operates.

The estimate of the impact of exposure to real estate developers in 1995-1997 on the yearly change in the NPL ratio is shown in Column 2 in Table 3 (panel A), and implies that an increase in the exposure to real estate developers from the mean of $4.0-5.0 \%$ increased the yearly change in the NPL ratio in 2009 by about $0.07 \%$ points. However, the impact was rather heterogeneous. The interaction of past specialization in real estate development with cumulative house price growth (row 2, column 2 in Table 3), is negative. That is, the exposure to real estate had a positive influence on the yearly change of the non-performing loans ratio that was mitigated by positive growth rates in real estate prices in the provinces where the bank operated. More precisely, the effect of exposure on the growth of the NPL ratio becomes negative for banks settled in provinces where the average growth rate of house prices between 2005:Q1 and 2008:Q4 exceeded $23 \%\left(0.23=\frac{0.07}{1.58}+0.187\right) .0 .187$ is the average house price increase between 2005 and 2008 (see Table 1) and it is subtracted from the house price increases in Tables 2, 3 and 4. The results are rather stable when we add further controls for the capital asset ratio in 1995 (column 3) or the NPL ratio in 1998 (column 4).

Figure 3 provides additional insights about the year when changes in housing prices affected NPL ratios. The figure shows OLS estimates of the response of the share of non-performing loans to exposure to real estate development in each year during the period 2005-2009. We evaluate the response of non-performing loans to exposure to real estate developers by evaluating the house price change between 2005:Q1 and 2008:Q4 at the 10th centile of the distribution of changes.

We note two results in Fig. 3. Firstly, exposure to real estate development and its interaction with house prices were not significant determinants of bank-specific increase in the NPL ratio between 2005 and 2007-periods when national housing 


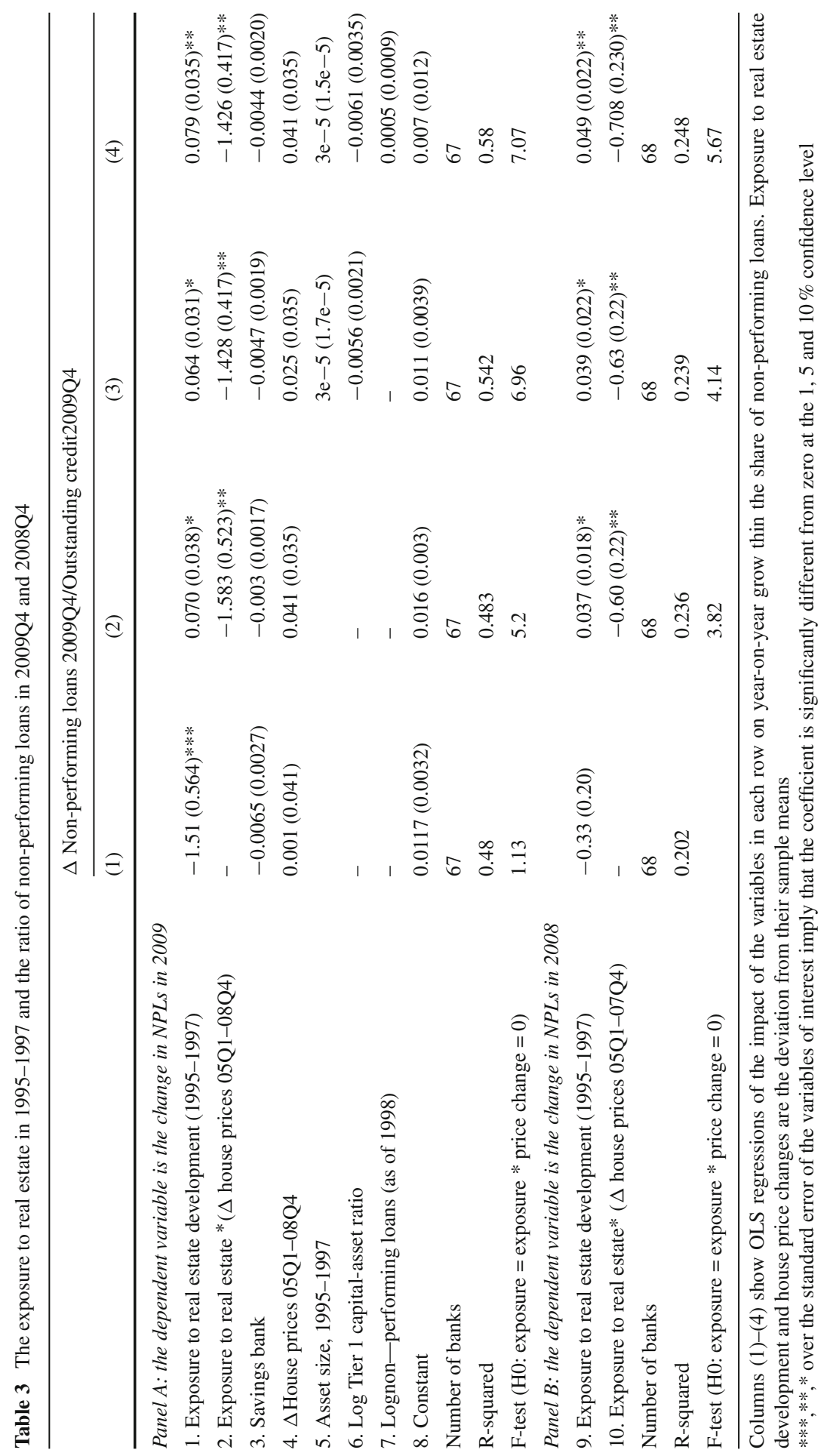




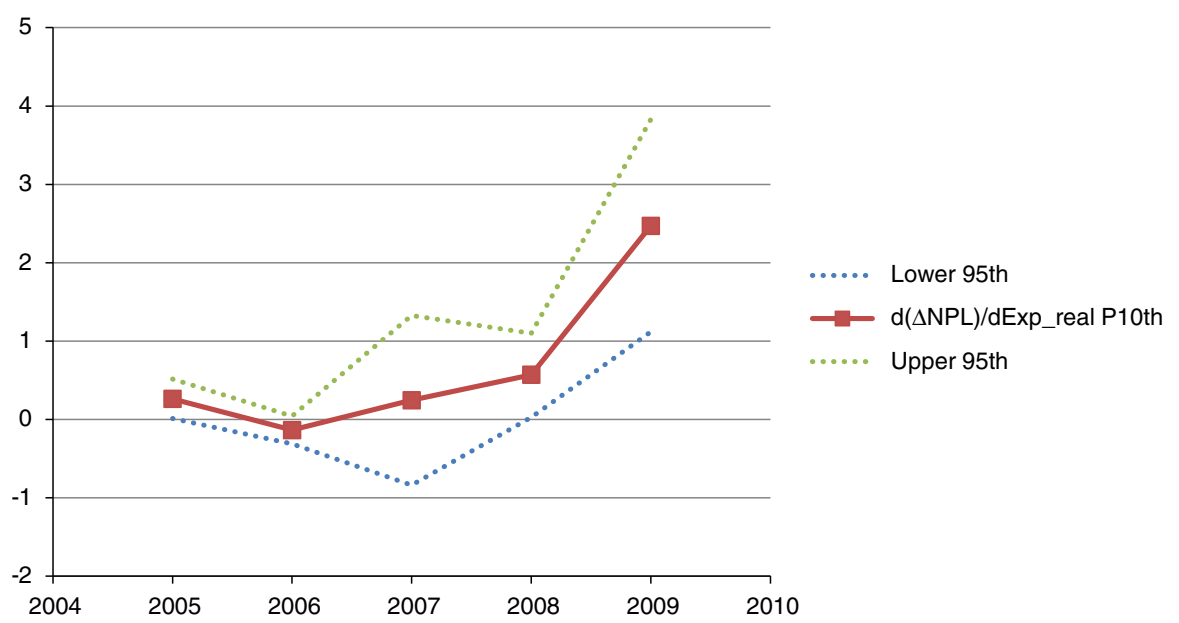

Fig. 3 The impact of exposure to real estate development on the yearly change of the NPL ratio, by year. Each dot is the predicted yearly change in non-performing loans over outstanding credit (the NPL ratio), evaluated at the median exposure to real estate development and the 10th centile of the distribution of bank specific changes of house prices between 2005Q1 and the year previous to the regression. Units are percentage points ( 2 means $2 \%$ increase in the NPL ratio). We run year-specific regressions for the period between 2005Q4 and 2009Q4 $\Delta N P L_{i, t}=\delta_{0}+\delta_{1}\left(\text { ExpReal }_{95-97}\right)_{i}+\delta_{2}\left(\text { ExpReal }_{95-97}\right)_{i} \Delta H P R I C E_{i, t}+$ $\delta_{3} \triangle H P R I C E_{i, t}+u_{i, t}$. Each dot is the point prediction $\hat{\delta}_{1}($ ExpReal $95-97) \cdot+\hat{\delta}_{2}($ ExpReal $95-97) *$ $\Delta H$ Price. Dashed lines are the limits of the 95 th confidence interval around each point estimate

prices were increasing. Only in 2008, 1 year after the price of real estate had started to fall in some provinces, the share of non-performing loans increased among banks initially exposed to real estate development. The response was highest among banks operating in provinces with lower house price increases.

As mentioned above, we find a statistically significant impact of exposure to real estate interacted with house prices on NPLs already in $2008 .{ }^{14}$ Interestingly, among banks exposed to real estate development, increases in loans default ratios preceded capital losses (for which Fig. 2 only finds evidence in 2009 and 2010). This is what one should expect, as due to regulatory reasons increases in non-performing loans affect capital growth only with a lag.

\subsection{Capital growth and business lending growth}

Table 4 reports the estimates of Eq. (6) both by OLS and TSLS. In the TSLS specification, capital growth and the change in the NPL ratio are instrumented using historical exposure to real estate development and its interaction with changes in the price of real estate in the provinces where banks operate. ${ }^{15}$

14 Table 3 Panel B presents the results on the change in NPLs during 2008. Cumulative housing price growth refers now to the period between 2005:Q1 and 2007:Q4. The estimates in Panel B have the same sign as, those in Panel A, but are smaller in magnitude.

15 The exposure to real estate mainly identifies changes in capital growth- the first and second columns of Table 2 show a very similar estimate of the impact of real estate development on capital growth. Furthermore, 


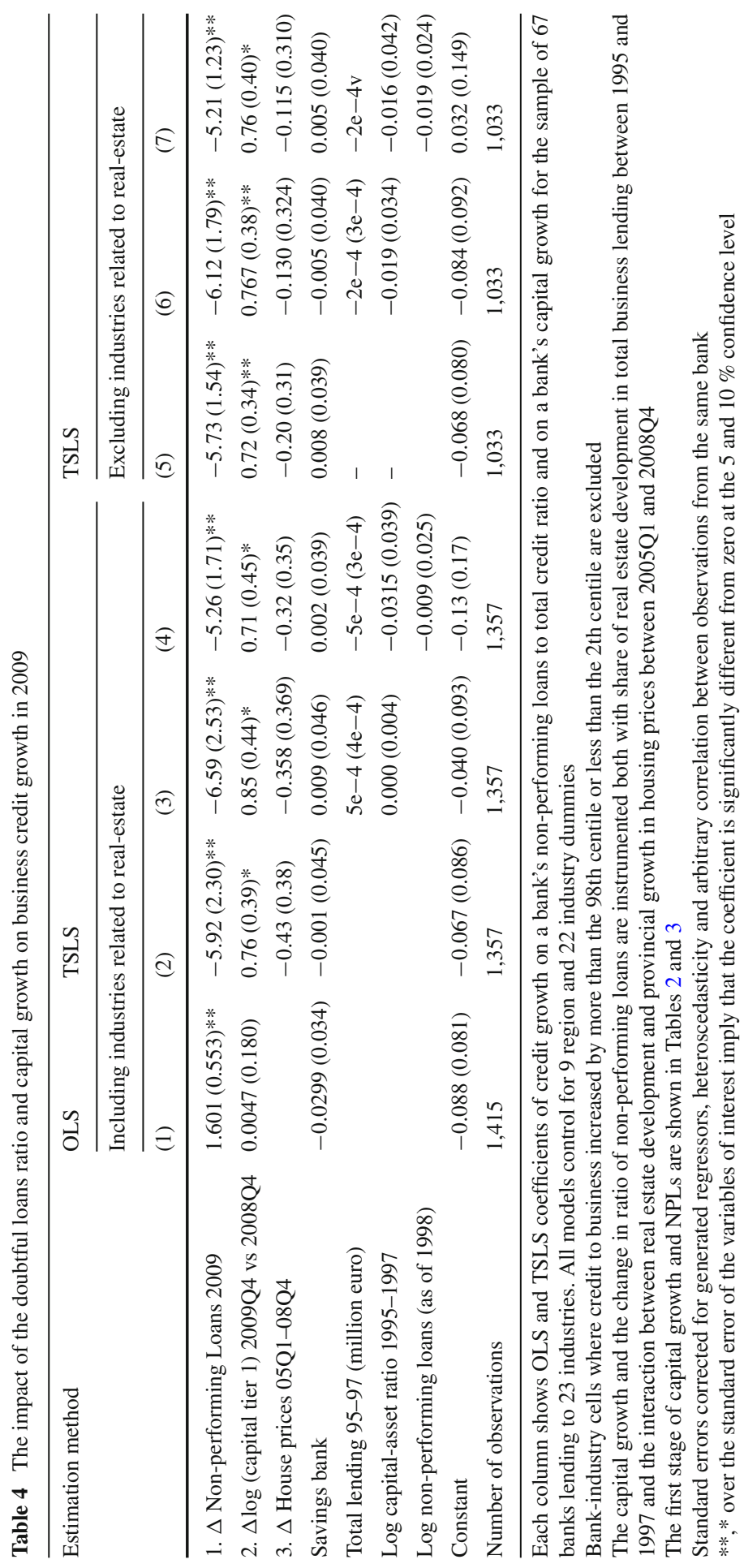




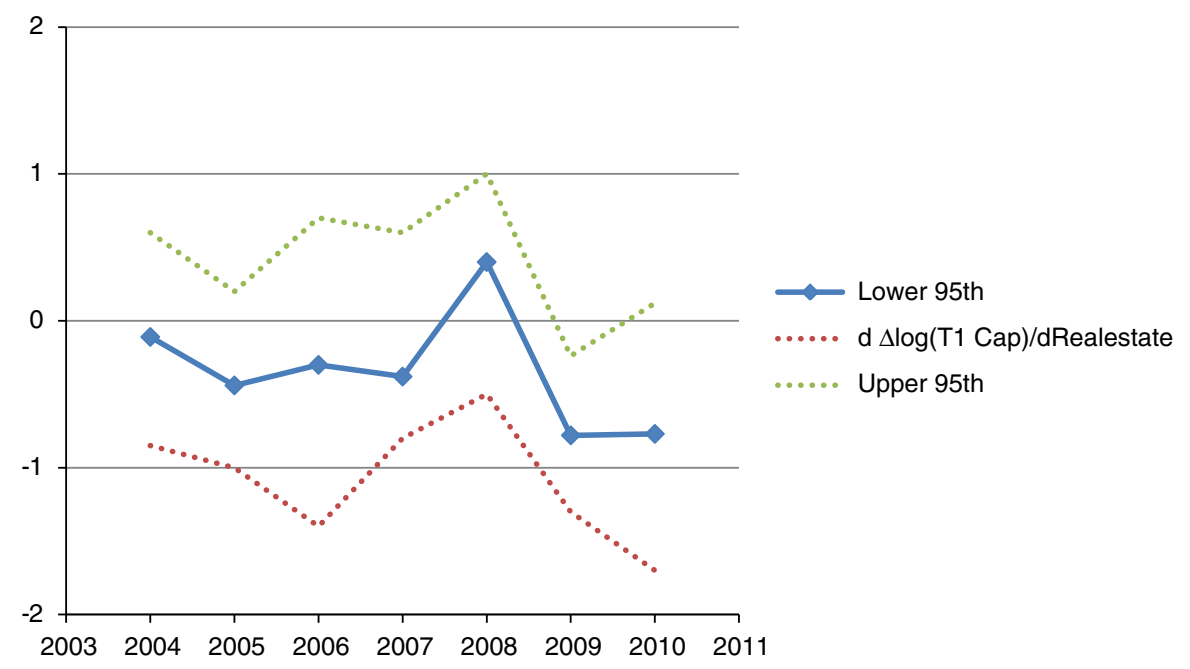

Fig. 4 The impact of exposure to real estate development on y-o-y growth in business lending, by year. Each dot is an estimate of the response of year on year credit growth to the bank's specialization in real estate development in 1995-1997. Point estimates are obtained from year-specific OLS regressions of credit growth to a specific industry on the bank's historical exposure to real estate development, 9 region and 23 industry dummies and a dummy for savings bank. The dashed lines are the limits of the 95th confidence interval

The coefficient of capital growth in the OLS regression (column 1) is 0.005 , very small and statistically not different from zero. In column 2, we show the TSLS estimated impact on business lending growth of capital growth, and the estimate is much larger, 0.76 (statistically significant at the $6 \%$ confidence level). Figure 4 provides insights about the sign and magnitude of such TSLS impact by regressing business lending growth directly on the instrument in each year between 2005 and 2009. ${ }^{16}$ Note that exposure to real estate development was negatively related to lending growth in 2009 and, possibly, in 2010 whereas it was not significantly different from zero in earlier years. In other words, unlike what the OLS coefficient in Table 4 suggests, exogenous falls in capital growth (due to the fact that banks were more exposed to real estate development) do affect lending growth negatively .

The usual argument in the literature is that the OLS estimate of the impact of capital growth on business lending growth is biased upward because lending and capital tend both to contract during recessions. One would also expect an upward bias of OLS estimates in the cross-section because banks lending to weaker firms (i.e., those that

Footnote 15 continued

the instrumented effect of capital growth on loan growth is basically the same when we only use exposure to real estate as an instrument-and do not include the share of NPLs in the TSLS regression.

16 The reason for looking at the OLS estimate of the impact of real estate development on growth in credit in 2009 ( -0.78 , depicted in Fig. 4) is that the TSLS estimate in row 2, column 2 of Table 4 should be approximately the ratio between that estimate and the OLS estimate of real estate development on capital growth $(-0.86$, in Table 2 column 1, row 1$)$. The approximation is exact when there is one single instrument and no covariates. 
are affected most by downturns in the business cycle) experience larger drops in capital. However, in Table 4 the OLS estimate is below the TSLS one.

A possible explanation for the negative bias in the OLS coefficient in Table 4 is that during the 2008-2009 period there was a general increase in the banks' capital ratios, as a result of the higher requirements by investors in financial markets and the expectations of more strict regulatory capital requirements. In particular, markets may have required higher capital increases for banks with worse business prospects (i.e., banks lending to weaker firms). The joint effect of capital increases required by financial markets and an adverse demand effect to a particular set of banks generates a negative correlation between $\Delta \log \left(K_{t}\right)$ and $\varepsilon_{i, t}^{j}$, biasing downward the OLS estimate of the effect of capital growth on lending growth.

The estimated elasticity of lending to capital is 0.76 for the whole sample of industries, and the results do not change much when we control for other pre-determined bank characteristics, such as asset size in 1995-1997, the average capital-asset ratio in the same period (column 3) or when we control for share of non-performing loans in 1998 (column 4). Finally, the estimates become more precise when we exclude construction-related industries (columns 5-7).

An elasticity of credit growth to capital growth of about 0.76 is substantially lower than the value of 3.84 reported in Peek and Rosengreen (1995) for their whole sample of banks. We have mentioned before that an estimate above one is hard to reconcile with our model. A possible explanation for the discrepancy between the results is that we hold constant anticipated capital drops by controlling for the change in nonperforming loans.

\subsection{Non-performing loans and the growth of business credit}

Table 4 also displays the response of business lending growth to the yearly growth in the doubtful loans ratio, holding capital growth constant. The OLS relationship between credit growth and the yearly change in the NPL ratio suffers from an upward bias if banks continue lending to troubled borrowers to avoid writing off large losses (i.e. if they incur in evergreening). Alternatively, the OLS estimate may suffer from a negative bias if worse banks are matched with worse borrowers. We find a positive and significant coefficient of the changes in the NPL ratio in the OLS regressions (see Table 4, column 1).

By using 13-year lagged industry exposure, biases due to specialization in worse customers are mitigated. Indeed, once we rely on variation in the NPL ratio associated to historical exposure to real estate development, the growth of the NPL ratio affects credit growth negatively. The finding suggests that credit granted to firms reacts negatively to anticipated falls in capital. ${ }^{17}$

17 We have re-estimated the basic models in Table 2, 3 and 4 using the one year change in housing prices instead of cumulative ones. That is, we used $\frac{P_{i, 2008 Q 4}-P_{i, 2007 Q 4}}{P_{i, 2007}{ }^{4}}$ as a proxy for $\triangle H P R I C E_{i, t-1}$ instead of using $\frac{P_{i, 2008 Q 4}-P_{i, 2005 Q 1}}{P_{i, 2005 Q 1}}$. The impact of exposure to real estate on capital growth is $0.765(0.38)$ and the interaction of exposure and housing prices changes is 0.14 , very similar to those in Table 2. For a specification comparable to that shown in Table 3, second column we obtain an impact of real estate 


\subsection{The magnitude of the estimates}

\section{Counterfactual distribution of exposure to real estate}

We quantify the magnitude of the impact of capital growth on business credit growth by conducting the following thought experiment: Had capital growth in 2009 evolved similarly for all banks, what would have been the growth in business lending? We assume that all banks with exposure to real estate development above the mean had the mean exposure in 1995-1997 (4.0\%). In that scenario, the counterfactual capital growth during 2009 would have been $10.7 \%$ (the observed one was $9.6 \%$ ). The model estimated in Table 4, column 2 delivers a counterfactual contraction of business credit in 2009 of $3.3 \%$, while the observed drop was of $4.0 \%$. Thus, the lower capital growth attributable to specialization in real estate in 1995-1997 accounts for $18 \%$ of the drop in business credit in $2009\left(0.175=\frac{0.04-0.033}{0.04}\right) .{ }^{18}$

\section{Counterfactual evolution of housing prices}

To evaluate the magnitude of the effect of the increase in the NPL ratio on business lending growth in 2009 we run a different counterfactual. What would have been the drop in business lending had the NPL ratio evolved as predicted by the model in column 2 of Table 3 but with house prices in 2008:Q4 staying at the 2007:Q4 level? We first compute the growth in the share of NPLs that would have been observed if the price of real estate had remained at the 2007:Q4 level. That level was 1.46\%, while the actual one was $1.51 \%$. Then we used this counterfactual ratio of non-performing loans to estimate what would have been the growth rate of lending in the alternative scenario of zero change in the price of real estate in 2008. Even without drops in real estate prices in 2008, the average growth rate of lending would have been $-3.3 \%$, while the average growth of business lending in 2009 for the banks in the sample was $-4.0 \%$. Thus, this channel would again explain around $18 \%\left(0.175=\frac{0.040-0.033}{0.04}\right)$ of the total contraction in loan supply in $2009 .{ }^{19}$ Rerunning the specification excluding lending to industries related to construction, we obtain that business lending dropped by $2.4 \%$ points, while the counterfactual with no price drop in 2008 amounts to a $1.9 \%$ points reduction. In that case, loan supply factors would contribute up to $21 \%$ of the observed drop in $2009\left(0.21=\frac{0.024-0.019}{0.024}\right)$.

\footnotetext{
Footnote 17 continued

exposure on change in NPLs of $0.53(0.4)$, while the interaction is -4.41 (1.92). Both estimates are also close to those reported in Table 3. Finally, the estimate of the impact of exposure to real estate developers on credit growth is similar to that reported in Table 8 Panel B. The main difference is that the TSLS estimates were less precise than the ones we show.

18 That estimate ignores the additional effect of changes in exposure to real estate on business lending that occurs through changes in the ratio of non-performing loans and anticipated drops in capital. However, we only study the current capital effects in this counterfactual.

19 Perhaps surprisingly, the magnitude of the credit drop in the counterfactual with constant house prices in 2008 is remarkably similar to that estimated when we change the distribution of exposure to real estate in 1995-1997.
} 


\section{The impact of the exposure to real estate development on other bank-level outcomes}

The two stage least squares (TSLS) estimates in Table 4 are valid under the assumption that the instruments Exp real95-97 and Exp real ${ }_{95-97} \triangle H P R I C E_{i, t-1}$ affect business lending only through their impact on contemporary and anticipated capital growth. However, banks specialized in real estate development lending may differ from the rest of institutions along other dimensions-say, they were especially dependent on external liquidity. In such a case the TSLS estimates in Table 4 would partly reflect the effect on business lending of spurious bank-level outcomes. We assess the relevance of potentially confounding factors by examining the impact of the instruments on a number of bank-level outcomes, including the share of industry-specific nonperforming loans, the growth of deposits, changes in bank liquidity and the interest rates charged on newly granted loans.

\subsection{NPL ratios by industry}

A first concern refers to the possibility that banks specialized in the real estate development sector lend disproportionately to firms prone to default at the beginning of a recession. Jiménez et al. (2010) document that, compared to other lending institutions, banks specialized in construction lend to small firms and grant loans that are tied to the value of the borrowers' real estate. A fall in the price of real estate may then harm the collateral value of those small firms, possibly inducing firm closures (as those firms cannot invest or get credit) and a higher share of NPLs. However, such a channel works through the firm's balance sheet and it is not a bank capital effect.

We address those concerns by examining the share of non-performing loans in each industry. Assume that banks historically exposed to real estate development in 1995-1997 lent disproportionately to the firms that mechanically borrow a fraction of their collateral. In the event of a fall in the price of real estate, those lending institutions would experience higher than average NPLs only because their typical customer relies on lending secured on property. Our assumption is that such reasoning ought to operate for any industry. The alternative hypothesis that banks exposed to real estate do not specialize in collateral-dependent firms predicts that the ratio of NPLs is orthogonal to historical exposure to real estate development for all industries but real estate development-which is obviously dependent on real estate prices.

Using balance sheet data of 2009:Q1 (the last period for which we have NPL ratios disaggregated by industry) we run industry-specific versions of model (8):

$$
\begin{aligned}
N P L_{i, t}^{J}=\delta_{0} & +\delta_{1}^{j} \operatorname{Exp} \underset{95-97}{\text { real }}+\delta_{2}^{j} \operatorname{Exp} \underset{95-97}{\text { real }} \Delta H P R I C E_{i, t-1} \\
& +\delta_{3}^{j} \Delta H P R I C E_{i, t-1}+d_{4}^{j} X_{i, t}+u_{i, t}^{j}
\end{aligned}
$$

If banks specialized in real estate lend to collateral-dependent firms, $\delta_{1}^{j}$ will be positive and $\delta_{2}^{j}$ negative-for all industries. We plot in Fig. 5 industry-specific estimates of the impact of the drops of house prices on loan repayment behavior $\left(N P L_{i, t}^{J}\right)$ 


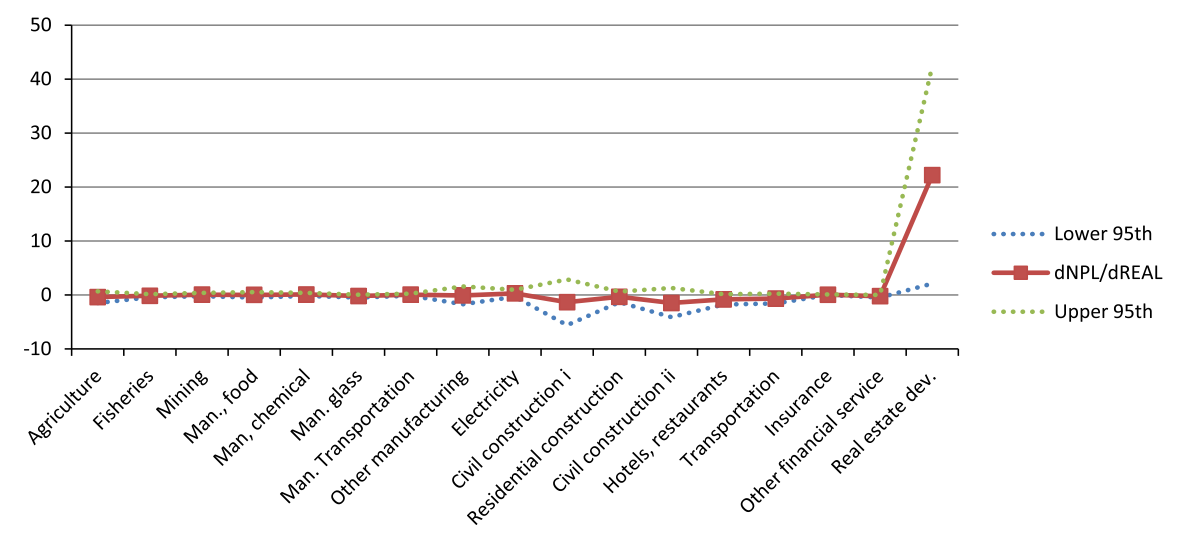

Fig. 5 The impact on the NPL ratio of real estate exposure to real estate development in 1995-1997 interacted with the change in house prices between 2005Q1 and 2008Q4. Each dot is the predicted ratio of non performing loans over outstanding credit (NPL ratio) evaluated at the median exposure to real estate development and the 10th centile of the distribution of bank of specific change of house prices between 2005Q1 and the year previous to the regression. Point estimates are predicted values from 22 industryspecific OLS regressions of industry-specific share of non-performing loans on historical exposure to real estate development, the growth between 2005Q1 and 2008Q4 of provincial house prices, region dummies and a dummy for savings banks. Trade is excluded because the estimates were very imprecise for that industry. Dashed lines are the limits of the 95th confidence interval

allowing for differences in the lender's exposure to real estate. Namely, we present $\delta_{1}^{j}+\delta_{2}^{j} \triangle H P R I C E_{i, t-1}$ where $\triangle H P R I C E_{i, t-1}$ is the 10th centile of the price change between 2005:Q1 and 2008:Q4 and $j$ denotes the industry. In other words, we evaluate the impact of exposure to real estate development on the NPL ratio in the provinces with highest price falls.

Figure 5 shows that $\delta_{1}^{j}+\delta_{2}^{j} \triangle H P R I C E_{i, t-1}$ is zero for all industries but real estate development. In other terms, the banks most exposed to real estate development in 1995-1997 faced relatively worse repayment rates only from real estate developers. Furthermore, those lower repayment chances were confined to the provinces with the highest drops in the price of houses. In sum, the evidence is not consistent with the hypothesis that banks exposed to real estate development were experiencing an increase in NPLs in 2009 because their customers' borrowing was very dependent on their collateral.

6.2 Alternative capital measures, deposit growth, liquidity and interest rate responses

The Spanish regulator requires banks to accumulate extra provisions during expansionary periods as a way of self-insuring against the risk of unrealized but latent losses when credit is expanded, and that "dynamic provisioning" buffer is included in tier 2 capital. Hence, we also explore the impact of the bank's exposure to real estate development and its interaction with house prices on capital growth using this broader measure of capital changes. The results are shown in the first two columns of Table 5 are quite similar to those in Table 2. 


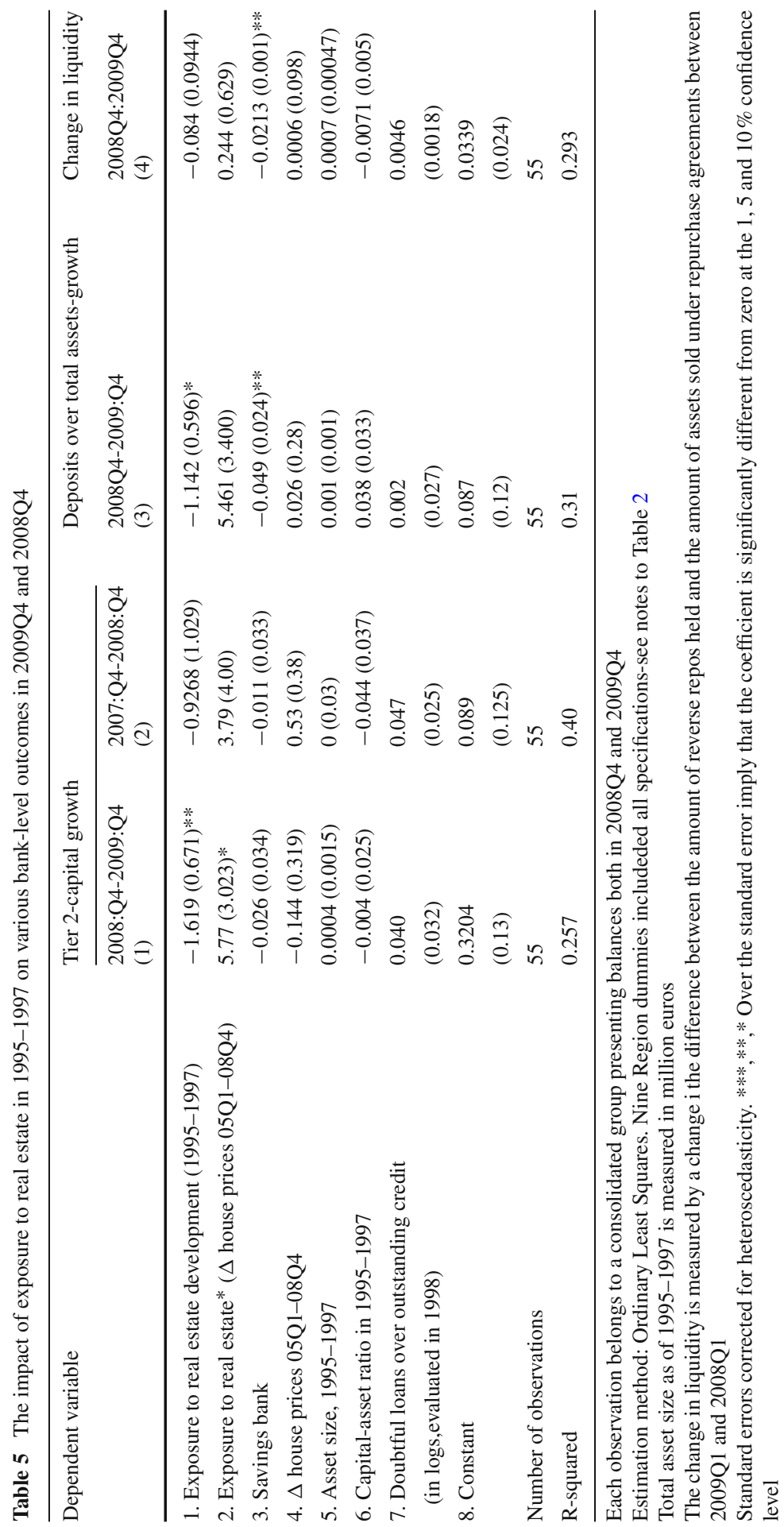




\subsubsection{Deposit growth and liquidity}

The link between capital growth and business lending could partially capture impacts of differences across banks in the growth of deposits or in their access to liquidity. For example, disruptions in the functioning of the interbank market may lead less liquid banks, or banks less able to attract depositors to cut business lending. Such confounding factors could bias the estimates in Table 4 if banks with heavier exposure to real estate development also experienced liquidity shortages or lower deposit growth. Table 5 presents the results of OLS equations of total deposit growth on exposure to real estate (column 3) and its interaction with local house prices (column 4). The results are somewhat unstable across specifications but suggest that, if anything, banks more exposed to real estate development faced higher deposit growth (albeit the link is not very precise). ${ }^{20}$

The last column of Table 5 examines how bank liquidity responds to exposure to real estate development. We measure bank liquidity using balance-sheet information on the bank's lending position in the interbank market and with respect to the ECB. We compute the value of the liquid assets as the balance of reverse repos held by the bank. Liquid liabilities are defined as the value of assets sold under repurchase agreements. Our measure of liquidity is the difference between both components. The estimates in Table 5, column 5 suggest that the bank's exposure to real estate development is a weak predictor of the yearly change in our measure of liquidity. ${ }^{21}$

\subsubsection{Interest rate responses}

An alternative explanation of the findings in Table 4 is contained in Santos (2011). He shows that banks specialized in subprime lending in the US reassessed the riskiness of their customers during the financial crisis and, as a result, increased the interest rates charged. In such a case, the observed fall in borrowing among their borrowers would be partly caused by a movement along a firm's demand curve for funds. In other terms, the amount of loans granted fell because loan terms became tighter, not because banks were capital constrained and cut the amount of funds lent. ${ }^{22}$ We study the role of such risk reassessment by testing if banks exposed to real estate development in 1995-1997 granted in 2009 loans with higher interest rates.

\footnotetext{
20 Nevertheless, when we introduce the interaction between exposure and housing prices, the relationship changes its sign. In view of the unstable relationship, we further included one year lagged deposit growth as a regressor in a model otherwise similar to that in column (8) of Table 4. The results (not shown) were unchanged, suggesting that the unstable relationship between deposit growth and lagged exposure to real estate does not bias the estimates.

21 Basel III proposes a finer measure of bank liquidity that compares liquid assets (where each particular asset receives a different weight) to liabilities due in 30 days. The information we have on the banks' balance sheets does not permit computing those measures in 2009.

22 Balance sheet effects can be interpreted as an inward shift of the whole loan supply curve, holding the borrower's quality constant. The alternative hypothesis we examine is that such inward shift is associated instead to a reassessment of the quality of borrowers.
} 
We use bank-level information on the amount of new loans originated quarterly as well as the interest rate charged by the bank on those operations. ${ }^{23}$ Table 6 shows the results of year-specific OLS regressions of interest rates on the same set of covariates as in Table 5. The bottom panel of Table 6 places the magnitudes in perspective by displaying the predicted interest rates for different levels of lagged exposure to real estate. Banks in the 10th centile of the distribution of real estate exposure charged about 25 bp lower interest rate than banks in the 90th centile of the distribution of real estate exposure. ${ }^{24}$ However, average interest rates on loans granted during the first quarter of 2009 were $200 \mathrm{bp}$ lower than the interest rates charged in the same period of 2008. Compared to the 200 bp drop in interest rates between 2008 and 2009, we doubt that the 25 bp cross-sectional difference in interest rates in 2009 can account for the fall in business lending that we document.

\subsection{Did firms reshuffle their debt portfolios?}

Firms may overcome bank-specific credit supply problems by substituting loans from stressed banks by new credit from unconstrained ones. Jiménez et al. (2010) discuss that such behavior induces a negative correlation between a bank's capital growth and the growth in the amount of credit granted by that bank to a given firm. However, that correlation is spurious and does not really reflect a cut in the total amount of credit that a firm has available. These authors also show that debt reshuffling can be identified in the data. Applied to our setting, their strategy amounts to comparing estimates of $\beta_{1}$ and $\beta_{2}$ in model (6) to similar estimates of the same model once it is aggregated at the industry level.

$$
\Delta \log L_{t}^{J}=b_{j}+b_{1} \sum_{i=1}^{i=N_{j}} \frac{\Delta N P L_{i, t}}{N_{j}}+b_{2} \sum_{i=1}^{i=N_{j}} \frac{\Delta \log K_{i, t}}{N_{j}}+d_{s} \sum_{i=1}^{i=N_{j}} \frac{X_{i, t}}{N_{j}}+\sum_{i=1}^{i=N_{j}} \frac{\varepsilon_{i, t}^{j}}{N_{j}}
$$

$\Delta \log L_{t}^{J}$ is loan growth at the industry level and the rest of the variables are industryspecific averages of the covariates of interest. The test is simple. Imagine that industries were able to replace the full amount of loans granted in $t-1$ by a bank with low capital growth with new loans granted in period $t$ by another bank with high capital growth. In such an extreme case, changes in the total amount of loans granted to industry $j$ would be unaffected by the characteristics of the banks that lent to that industry in moment $t-1$. In other words, $b_{2}$ would be zero. However, $\beta_{2}$ would still be positive because banks with low capital growth lend less to each industry than banks with high capital

\footnotetext{
23 Lending institutions provide information on interest rates split by loan size (below and above 1 million euro) and maturity - reported in three brackets: below 1 year (some $70 \%$ of total lending) between 1 and 5 years and above 5 years. Unfortunately, not all banks provide such information, so we use a selected sample of 45 institutions.

24 To compute the 10th and 90th centile, the distribution of real estate exposure was weighted by the mean bank assets of the bank during the 1995-1997 period.
} 


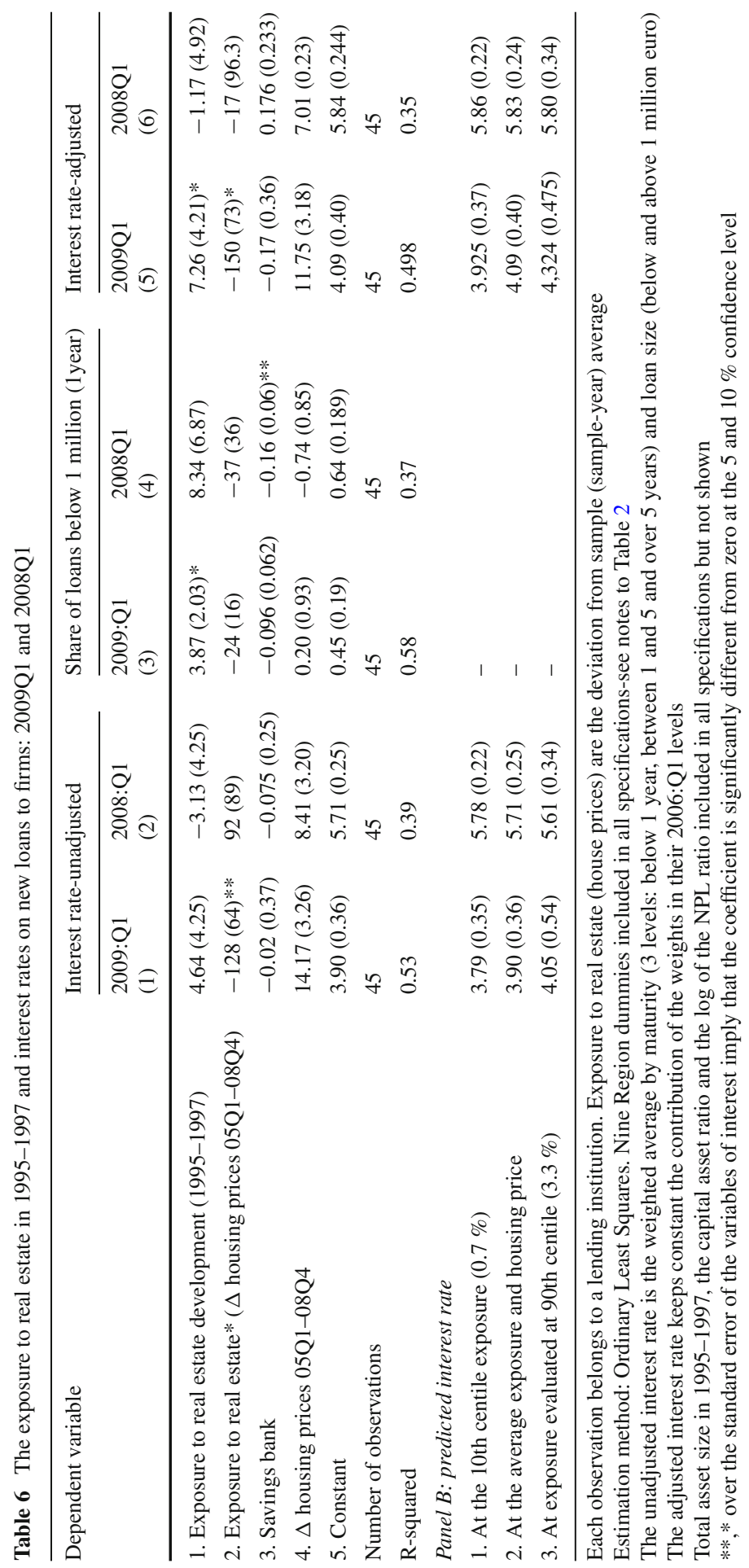




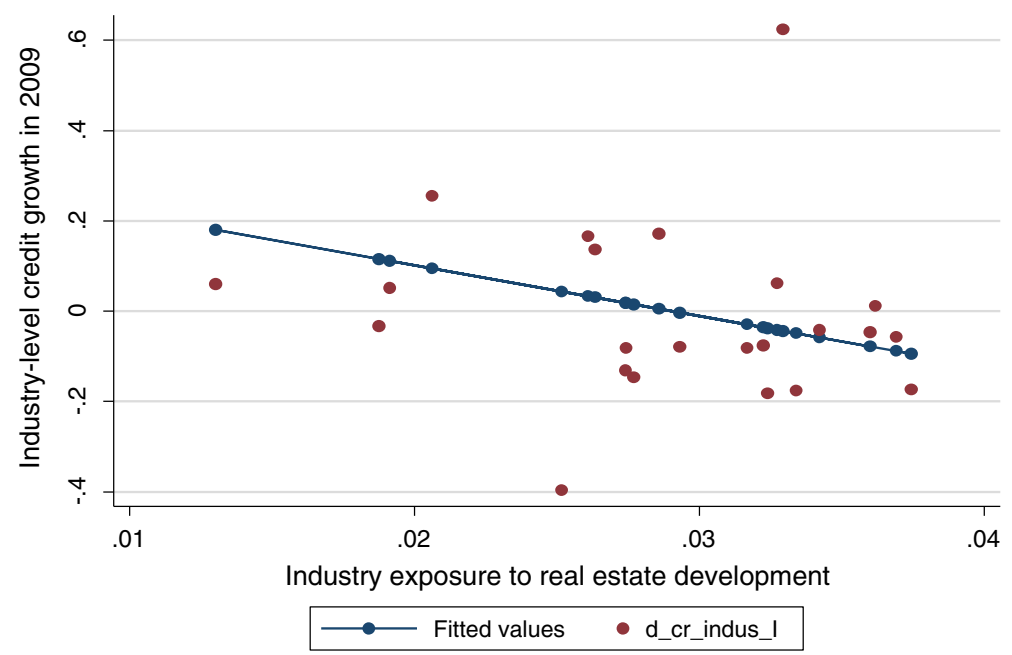

Fig. 6 Credit growth in 2009 and average exposure to real estate development of bank lenders-by industry. The variable in the horizontal axis is an average of exposure to real estate in 1995-1997 across all banks that lent to the industry in 2008Q4. The vertical axis contains annual credit growth in 2009 at the industry level. The solid line is a set of fitted values based on a regression of credit growth to an industry on the share of savings banks lending to that industry and the average exposure to real estate development among banks lending to the industry. The coefficient of exposure to real estate development is $-0.10(0.06)$, shown in Table 7

growth. More generally, substitution among borrowers implies that, in absolute value, $b_{2}<\beta_{2}$.

We test for debt reshuffling by adapting model (10). Namely, we regress credit growth of industry $j\left(\Delta \log L_{t}^{J}\right)$ on the exposure to real estate development of the average bank lending to that industry $j$. That is, the regressor is the average exposure to real estate development in 1995-1997 of all banks that were lending to industry $j$ in 2007. We then compare that (industry-level) estimate to the OLS estimate of the impact of a bank's exposure to real estate development in 1995-1997 on credit growth using a bank-industry sample.

Figure 6 shows a scatter plot of data where the vertical axis shows credit growth of each of the 22 industries in our sample and the horizontal axis shows to what extent each industry was borrowing from banks traditionally exposed to real estate development. Clearly, industries that in 2007 borrowed relatively more from banks with traditional expertise on lending to real estate developers experienced significantly lower credit growth in 2009. The dependence of the amount of credit granted to an industry on the characteristics of banks that lend to the industry is clearly at odds with the hypothesis of debt reshuffling. The quantitative results in Table 7 reinforce the evidence in the Fig. 6. In Table 7, column 3, row 1a, an increase of $1 \%$ point in the average exposure to "real estate banks" at the industry level diminishes the growth in credit granted to that industry by $10 \%$ points, much larger in absolute value than the bank-industry estimate of bank exposure to real estate development: -0.77 in column 1 of Table 7 . We infer that while obtaining credit from alternative borrowers can be an option during 
Table 7 Did firms reshuffle their debt portfolios?

\begin{tabular}{|c|c|c|c|}
\hline & $\begin{array}{l}\text { Bank-industry } \\
\text { level regression } \\
\text { OLS } \\
\log (\text { Cred09Q4) - } \\
\log (\text { Cred08Q4) } \\
\text { (1) }\end{array}$ & $\begin{array}{l}\text { Bank-industry } \\
\text { level regression } \\
\text { OLS } \\
\log (\text { Cred09Q4) - } \\
\log (\text { Cred08Q4) } \\
(2)\end{array}$ & $\begin{array}{l}\text { Industry-level } \\
\text { regression } \\
\text { OLS } \\
\log (\text { Cred09Q4) - } \\
\log (\text { Cred08Q4) } \\
\text { (3) }\end{array}$ \\
\hline $\begin{array}{l}\text { 1. Exposure to real estate } \\
\text { development in 1995-1997 }\end{array}$ & $-0.777(0.297)^{* *}$ & $-0.882(0.308)^{* *}$ & \\
\hline $\begin{array}{l}\text { 1a. Mean exposure to real estate } \\
\text { development (industry average) }\end{array}$ & & & $-10.25(6.501)^{*}$ \\
\hline 2. Savings bank & $-0.071(0.032) * *$ & $-0.071(0.032) * *$ & \\
\hline $\begin{array}{l}\text { 2a. Mean of savings bank lending to } \\
\text { the industry (industry average) }\end{array}$ & & & $-0.088(0.015)^{* *}$ \\
\hline 3. Constant & $0.0428(0.026)$ & $0.0154(0.034)$ & $0.834(0.233)$ \\
\hline Sample size & 1,033 & 1,033 & 22 \\
\hline Industry fixed-effects? & No & Yes & No \\
\hline
\end{tabular}

The sample used in columns 1 and 2 has as many observations as bank-industry cells we observe in 2009Q4 (67 banks, 23 industries). The sample excludes cells where lending was above the 98th centile or below the 2nd centile

The coefficients in columns 1 and 2 are estimated by OLS using the bank-industry sample. We include the rest of the regressors mentioned in Table 4, column 7

The sample used in column 3 has as many observations as industries we observe in our sample (22 after excluding real estate development)

The coefficients of column 3 are OLS estimates of a regression of industry credit growth in 2009 on the average exposure to real estate development among lenders to the industry and the fraction of lenders that are savings banks

$* *, *$ over the standard error of the variables of interest imply that the coefficient is significantly different from zero at the 5 and $10 \%$ confidence level

an expansion (as findings in Jiménez et al suggest), there were limited possibilities of switching loan suppliers during the sample period we analyze. ${ }^{25}$

\section{Exposure to real estate development and loan-level outcomes}

The final set of specifications uses matched data on banks and firms to test if the estimates in Table 4 reflect the influence of any residual variable that is correlated both with the demand of loans and with the bank's exposure to real estate development. In addition, we provide some information on the distribution of loan cuts by firm size.

\footnotetext{
25 Bentolila et al. (2013) also document, among other findings, that Spanish firms that borrowed from weak banks at the onset of the 2008 recession were not able to replace the amount of loans granted by those institutions with new loans from other institutions. However, Banco de España (2013) documents rather different results. Note that we focus on banks exposed to real estate developers in 1995-1997, a set that does not fully overlap with the set of banks that those authors examine.
} 


\subsection{Loan level data}

We examine the impact of bank's exposure to real estate development on loan's yearly growth, where a loan is defined as the total liability that a firm $f$ has with a bank $i$. This specification permits the inclusion of firm-year fixed effects, which fully absorb the solvency of a firm in a given year. We run different versions of the following model

$$
\begin{gathered}
\Delta L_{i, 2009}^{f}=\alpha_{0}+\alpha_{1} \operatorname{Exp} \underset{95-97}{\operatorname{real}}+\alpha_{2} \operatorname{Exp} \underset{95-97}{\operatorname{real}} \Delta H P R I C E_{i, 2008} \\
+\alpha_{3} \Delta H P \operatorname{PIC} E_{i, 2008}+d_{4} X_{i, 2009}+\theta_{f}+\varepsilon_{b, t}^{f}
\end{gathered}
$$

where $\Delta L_{i, 2008}^{f}=\frac{L_{i, 2009}^{f}}{L_{i, 2008}^{f}}-1$ reflects year-on-year growth of the loan amount given by bank $i$ to firm $f$ in 2009 and the rest of the variables have been defined already. ${ }^{26}$ By including the firm-year fixed effect $\theta_{f}$, the coefficient $\alpha_{1}$ measures if the banks that were most exposed to real estate development in 1995-1997 cut more their lending to a given firm than the rest of lending institutions. Furthermore, we also examine the robustness of the parameters of interest $-\alpha_{1}$ and $\alpha_{2}$-in models that include and exclude the firm fixed-effect $\theta_{f}$. If the magnitude of the estimates $\alpha_{1}$ and $\alpha_{2}$ are not altered by the inclusion of the exhaustive set of firm quality indicators $\theta_{f}$ one can establish that Exp real $_{i, 95-97}$ and Exp real r,95-97 $\Delta H P R I C E_{i, 2008}$ are indeed orthogonal to the solvency of the borrowers. In other words, exposure to real estate developers back in 1995-1997 reflects actual shocks to the banks' loan supply curve in $2009 .^{27}$

The results in Table 8 show that controlling for the unobserved quality of borrowers by means of firm-level fixed effects does not affect the role of exposure to real estate development in reducing credit supply. The estimate of $\alpha_{1}$ is shown in Table 8 Panel A, and amounts to -1.93 (standard error: 0.62 ) when we do not include firm fixed effects. That is, a $1 \%$ increase in the bank's exposure to real estate development in 1995-1997 reduces lending growth in 2009 by $1.93 \%$. Once we include firm fixed effects, the estimate is -1.857 (standard error: 0.811 ), a remarkably similar estimate. Furthermore, the inclusion of firm-year fixed effects increases the R squared of model (11) from 2 to $68 \%$. The robustness of the estimate of Exp real $95-97$ once we account for a large share of unobservables strongly suggests that the non-random matching of firms and banks is definitely not driving our estimates of the impact of exposure to real estate development on business credit growth.

The estimate of $\alpha_{2}$ is 14.03 (st. error 3.64), positive and precisely estimated. The estimate implies that banks specialized in real estate development as of 1995-1997

\footnotetext{
26 We do not use logs because $9 \%$ of firms in our sample did not have any loan in 2009, and such transition may be an effect of the contraction of bank's loan supply. Those cases would be missing in a sample that uses logs.

27 We weight each cell by $L_{i, 2008}^{f}$ to achieve comparability of the estimates with the analysis at the bankindustry level. The average of the bank-firm specific rates of growth in lending weighted by $L_{i, 2008}^{f}$ is identical to the aggregate rate of credit growth in 2009, because STATA automatically rescales weights by the total sum in the sample.
} 


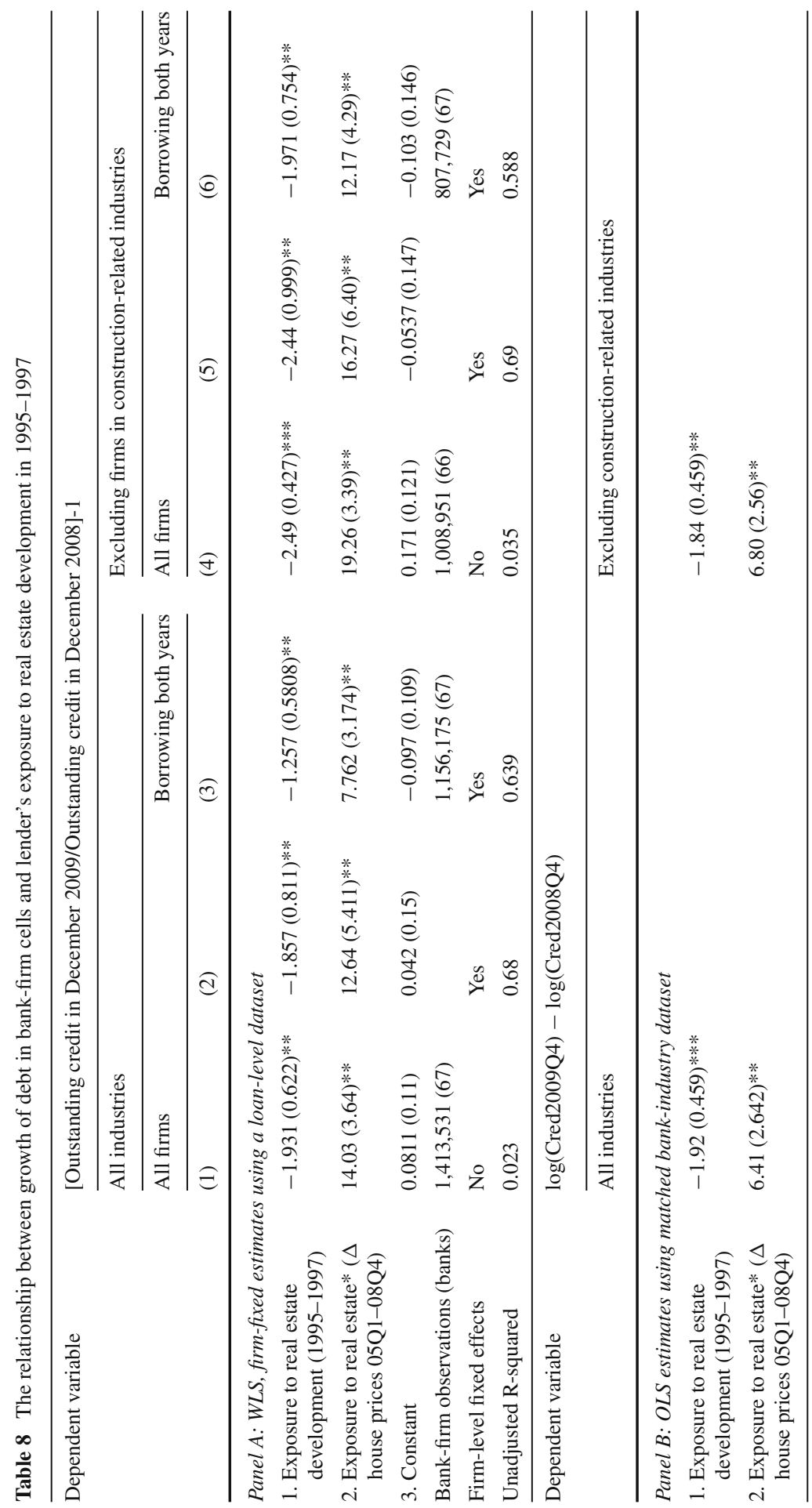




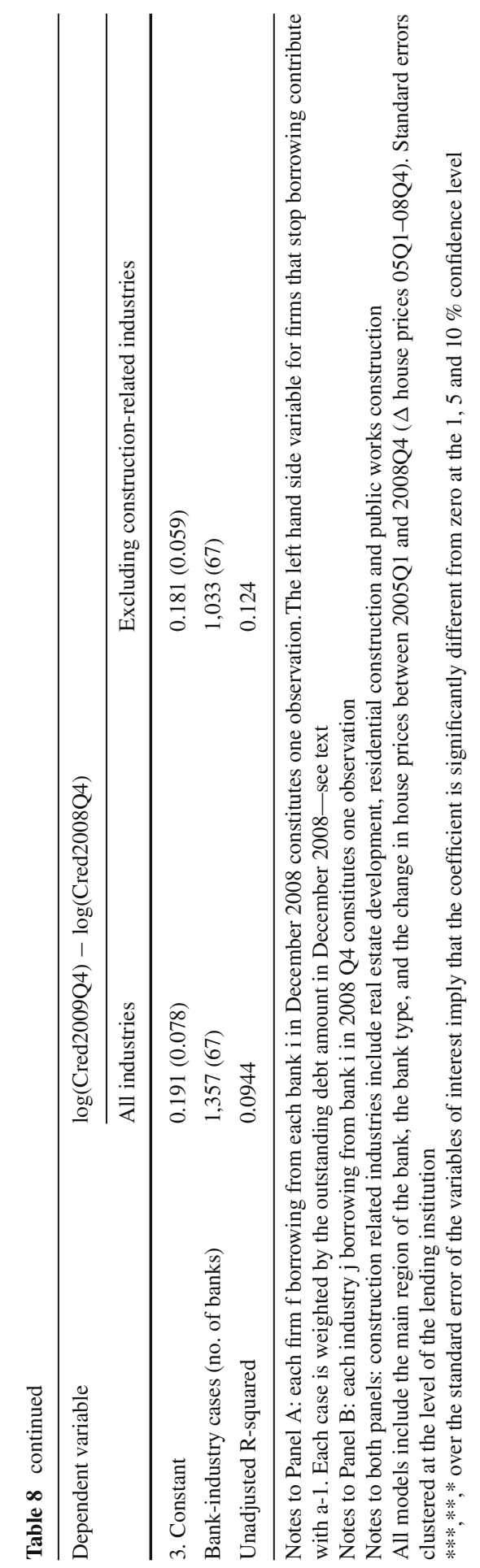


cut their lending more in 2009, and that the drop in lending was mitigated if those banks operated in provinces with lower house price increases. To provide a sense of the magnitude of the estimate, assume that a bank has an exposure to real estate development in 1995-1997 at the sample mean (0.040) and that it operates in provinces with the average house price increase of $15 \%$ between 2005 and 2008. Another bank operating in the same provinces but with a $1 \%$ higher exposure to real estate lending would reduce the amount of loans granted in 2009 by $1.84 \%$ more $(1.84=-1.93+$ $14.03 * 0.15)$. If both banks operated instead in a set of provinces with a $5 \%$ increase in housing prices (the 10th decile of house price increases), the differential fall in business lending granted by the bank with the highest exposure would be $1.90 \%$ instead $(1.90=-1.93+14.03 * 0.05)$. Albeit statistically significant, the impact of the bank's exposure to real estate development on business lending is not very different in provinces in the bottom decile of the price change (1.90\% drop in business lending) and at the mean house price change (1.84\% drop).

Two notes are in order. Firstly, the magnitude of the estimate of $\alpha_{2}$ does not depend at all on whether or not we control by firm fixed effects. The estimate is 12.64 (the standard error is 5.41) with firm-year fixed effects and 14.03 without them. The result has a very interesting interpretation. Firm-year fixed effects absorb the impact of changes in house prices in the location of the firm. Hence, the finding that $\alpha_{2}$ remains unaffected when we include firm-year fixed effects indicates that the cut in business lending is exclusively driven by the evolution of housing prices in the provinces where the bank (rather than the firm) operates. That result suggests that a fall in the price of real estate in a region where banks operate results in a reduction of business loans in other regions where the same bank lends. That is, local real estate shocks propagate to the loan supply in other regions through the bank's balance sheets.

In addition, Table 8 permits an explicit comparison between estimates of model (11) estimated at the bank-loan level and estimates of the same coefficients on a bankindustry sample. The estimates in the top panel—obtained in a sample that matches banks and firms - are remarkably similar to those in the bottom panel-obtained in a sample that matches banks and industries sample. The robustness of the estimates across disaggregation levels and estimation methods confirms that banks exposed to real estate developers at the beginning of the boom shifted inward their credit supply curve, holding borrower's quality constant. More generally, the invariance of results across samples does suggest that bank-industry data goes a long way in detecting bank balance sheet effects. This is an important result, as bank-level data is typically the only information available in countries that lack comprehensive credit registers.

\subsection{The distribution of the fall in business lending}

The use of loan level data permits an assessment of the distribution of the cut in business lending across firms of different sizes. Namely, we can estimate the impact of bank's specialization in real estate development in 1995-1997 on the evolution of credit granted to firms with different sizes. We conduct the exercise by matching credit registers to information on the balance sheet data of firms that borrow. Using 
firm identifiers, we achieved successful matches for about $40 \%$ of the Credit Register Records-consistent with previous studies.

Table 9 presents regression models like the one in (11), but now providing separate estimates of the impact by firm size. A $1 \%$ increase in specialization in real estate reduces loan growth by $4 \%$ among firms with less than three employees (Table 9, Panel A, row 1 column 2). The corresponding estimate among the largest set of firms $(250+$ workers $)$ is 3.3 and $2.7 \%$ among firms with 50-250 employees. However, the estimates are not statistically different from each other. Those estimates are at odds with the hypothesis that small firms are especially sensitive to cuts in bank lending.

\section{Conclusions}

Bank credit to the non-financial private sector in the Spanish economy has slowed sharply, from annual growth rates well above $20 \%$ in 2007 to negative figures registered at the trough of this cycle. The assessment of the relative contributions of demand and supply-side factors faces two main obstacles. The first is that Bank Lending Surveys, the sources of information that explicitly distinguished between supply and demand factors, are mainly qualitative. Secondly, business credit and bank balance sheets move simultaneously along the cycle.

This paper analyzes whether banks' contemporary and expected capital growth influences loan supply to a given industry and/or firm. We argue that the deleveraging process under way in the banking system (driven both by expectations of higher regulatory capital requirements and by greater demands from financial markets) in the case of some banks might have not been enough to meet the increase in capital requirements. This is likely to be the case for those institutions with limited access to market funding, either because of institutional limitations or as a consequence of higher perceived risk (as might be the case, for instance, of banks with a high exposure to real estate developers). These institutions might have been able to raise own funds only by retaining profits, and this channel might have been insufficient to reach the desired level of capital. Under these circumstances, these banks might have had to cut back on their lending.

Using financial statements for a sample of Spanish banks matched to registers of business credit at the bank-industry and bank-firm level, we have estimated different specifications for the separate impact of changes in banks' actual and expected capital growth on bank lending. We have used an instrumental variable approach together with industry-year and firm-year fixed-effects to control for the simultaneity of supply and demand factors. We show that the historical exposure to real estate development is a good instrument for banks' actual capital growth and that lagged exposure and its interaction with local housing prices affects the share of NPLs and, hence, future capital growth. Overall, banks' capital growth has been a relevant factor in explaining loan supply in 2009 and, possibly, in 2010. Our estimates imply that the elasticity of credit growth to capital growth lies between 0.7 and 0.8 . Our interpretation is that banks that have experienced capital shortfalls or banks that have increased their capital but without reaching the level demanded by financial markets might have had no option but to reduce their lending. 


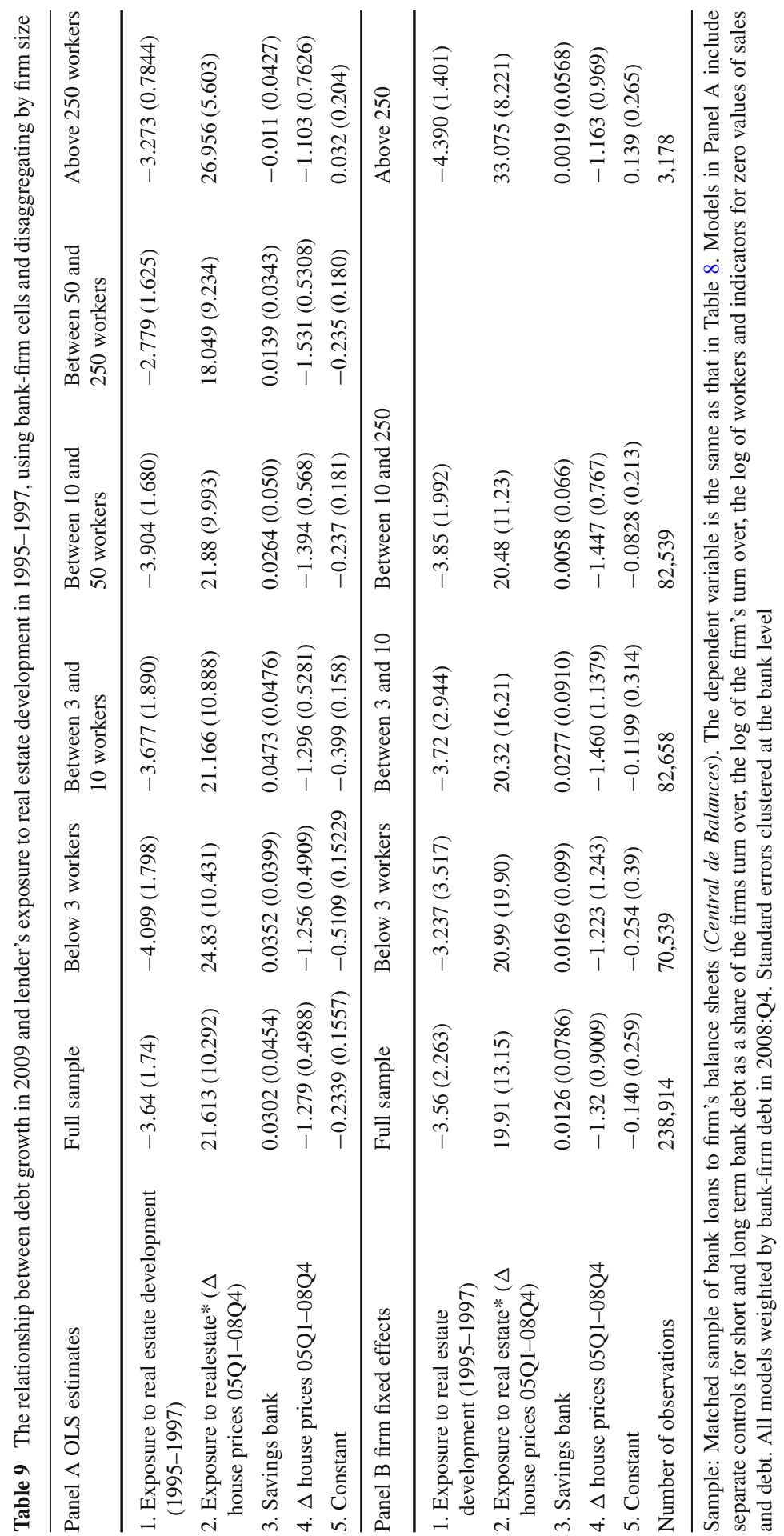


The assessment of the magnitude of the effect suggests that the contraction in lending stemming from the deterioration in banks' capital position associated with the fall in house prices accounts for between 18 and $21 \%$ of the observed decline in lending growth in 2009. The relatively small magnitude of this effect is explained by the weakness of loan demand in a context of deep recession. However, as loan demand reacts to the economic recovery, the capital position of particular institutions might have become more binding and this channel might have gained in strength in subsequent years. Future work could then examine if the more recent changes in house prices and their interaction with banks' specialization patterns has affected outcomes other than the supply of credit, such as employment levels.

Open Access This article is distributed under the terms of the Creative Commons Attribution License which permits any use, distribution, and reproduction in any medium, provided the original author(s) and the source are credited.

\section{Appendix}

The model is adapted from Van den Heuvel (2002). An infinitely-lived bank maximizes the expected stream of dividends $d_{t}$. The bank borrows at an interest rate $r_{t}$ and keeps a level of capital $K_{t}$. The bank uses those funds to lend an amount $L_{t}$ to firms obtaining a return $R\left(L_{t}\right)$ per unit lent. We further assume that the returns $R\left(L_{t}\right)$ is decreasing in $L_{t}$. The level of bank's capital can be increased by retaining post-tax profits $(1-\tau) \pi_{t+1}$ and it diminishes when the bank pays dividends.

We assume that the level of capital must exceed a minimum legal amount that is a fraction of the bank's total amount lent $\gamma_{L} L$ plus an amount required by the markets or arising from precautionary motives.

$$
\begin{aligned}
& \max _{d_{t}, L_{t}} \sum_{t=0}^{\infty}\left[\frac{1}{1+r_{t}}\right]^{t} d_{t} \\
\text { s.t. } K_{t+1}= & K_{t}+(1-\tau) \pi_{t+1}-d_{t} \\
\pi_{t+1}= & {\left[R\left(L_{t}\right)-r_{t}\right] L_{t}+d_{t}-K_{t} } \\
K_{t}-d_{t} \geq & \left(\gamma_{L}+\gamma_{U}\right) L_{t} \\
d_{t} \geq & 0
\end{aligned}
$$

The value function can be written as follows

$$
\begin{gathered}
V\left(K_{t+1}\right)=\max _{\{d, L\}} \quad d_{t}+\frac{1}{1+r_{t}}\left[V\left(K_{t}\right)+(1-\tau) \pi_{t+1}-d_{t}\right] \\
\text { s.t. } \quad K_{t}-d_{t} \geq\left(\gamma_{L}+\gamma_{U}\right) L_{t} \quad\left(\varphi_{t}\right) \\
\text { s.t. } \quad d_{t} \geq 0 \quad\left(\theta_{t}\right)
\end{gathered}
$$


The first order conditions of the problem are the following

$$
\begin{aligned}
\frac{\partial \vartheta}{\partial d_{t}} & =1-\frac{\left[1+(1-\tau) r_{t}\right]}{1+r_{t}} \frac{\partial V_{t+1}}{\partial K_{t+1}}-\varphi_{t}+\theta_{t}=0 \\
\frac{\partial \vartheta}{\partial L_{t}} & =\frac{[1-\tau]}{1+r_{t}} \frac{\partial V_{t+1}}{\partial K_{t+1}}\left[R^{\prime}\left(L_{t}\right)-r_{t}\right]-\varphi_{t}\left(\gamma_{L}+\gamma_{U}\right)=0
\end{aligned}
$$

where $\vartheta$ is the Lagrangian of the constrained maximization problem and $\mathrm{V}$ is the value function. The first condition says that the dividend policy must be such that the benefit of distributing one additional euro must equal the associated cost: less capital accumulated for next period and less funds available for lending, on top of the cost when the regulatory constraint binds $\varphi_{t}$ or the financial constraint that no additional capital can be raised $\left(\theta_{t}\right)$.

The second condition shows that banks must lend until the return of the last euro invested equals its cost, both in terms of the cost of funding $r_{t}$ and the cost in terms of the capital requirement.

Finally, the envelope theorem condition is the following:

$$
\frac{\partial V_{t}}{\partial K_{t}}=\frac{\left(1+(1-\tau) r_{t}\right)}{1+r_{t}} \frac{\partial V_{t+1}}{\partial K_{t+1}}-\varphi_{t}
$$

We start by examining the case when the financial constraint does not bind-or $\theta_{t}=0$. In that case, combining the envelope condition and the first order condition for the dividend policy, one obtains that $\frac{\partial V_{t}}{\partial K_{t}}=1$, which in turn implies that

$$
\varphi_{t}=\frac{\tau r_{t}}{1+r_{t}}
$$

And the lending policy is:

$$
M R\left(L_{t}\right)=r_{t}-\frac{\tau r_{t}}{1+r_{t}}\left(\gamma_{L}+\gamma_{U}\right)
$$

We denote $L_{t}^{*}$ as the amount of lending that solves (13). Importantly, the lending policy is determined by the marginal cost of funds, that combines the cost of raising funds and the cost of the regulatory constraint. The amount of lending does not depend on the capital position of the bank. If $\tau=0$, the regulatory constraint does not even enter the decision of how much to lend.

It can be shown that in this setting, the regulatory constraint always binds, as carrying excess capital is suboptimal under perfect certainty.

We assume that there is an initial distribution of values $\gamma_{U}^{0}$. Assume that either because capital markets require higher capital levels or because higher losses due to a change in the expectations about housing prices, the capital level of the bank falls short of the new amount needed, i.e., for all banks such that

$$
K_{t}+d_{t}=\left(\gamma_{U}^{0}+\gamma_{L}\right) L_{t}^{*}<\left(\gamma_{U}^{0}+\gamma_{L}\right) L_{t}^{*}
$$


Hence, in the new regime, $L_{t}^{*}$ does not satisfy the regulatory constraint and the bank's optimal lending policy $L_{t}$ is constrained by its capital

$$
L_{t}=\frac{K_{t}}{\gamma_{L}+\gamma_{U}}
$$

\section{References}

Albertazzi U, Marchetti D (2010) Credit supply, flight to quality and evergreening: an analysis of bank-firm relationships after Lehman. Banca d'Italia working paper no. 756

Banco de España (2013) Annual report 2012. Banco de España, Madrid

Berger A, Udell G (1994) Did risk-based capital allocate bank credit and cause a 'credit crunch' in the United States? J Money Credit Bank 26:585-628

Bernanke B, Lown C (1991) The credit crunch. Brook Papers Econ Activity 1991(2):205-239

Berrospide J, Edge R (2010) The effects of bank capital on lending: what do we know, and what does it mean? Int J Cent Bank 6(4):1-50

Bentolila S, Jansen M, Jimenez G, Ruano S (2013) When credit dries up: job losses in the great recession. Manuscript, CEMFI

Chaney T, Sraer D, Thesmar D (2012) The collateral channel: how real estate shocks affect corporate investment. Am Econ Rev 102(6):2381-2409

Cuñat V, Cvijanović D, Yuan K (2014) Within bank transmission of real estate shocks. London School of Economics

Francis W, Osborne M (2009) Bank regulation, capital and credit supply: measuring the impact of prudential standards. Occasional paper no. 36, UK Financial Services Authority, London

Gan J (2007) The real effects of asset market bubbles: loan-and firm-level evidence of a lending channel. Rev Financ Stud 20(6):1941-1973

Hancock D, Wilcox J (1993) Has there been a 'capital crunch' in banking? the effects on bank lending of real estate market conditions and bank capital shortfalls. J Hous Econ 3:31-50

Jiménez G, Mian A, Peydró JL, Saurina J (2010) Estimating the aggregate impact of credit supply channel: evidence from securitization in Spain. Mimeograph, Banco de España

Jiménez G, Ongena S, Peydró JL, Saurina J (2012) Credit supply and monetary policy: identifying the bank balance-sheet channel with loan applications. Am Econ Rev 102(5):2301-2326

Kashyap A, Stein J (2000) What do a million observations on banks say about the transmission of monetary policy? Am Econ Rev 90:407-428

Khwaja A, Mian A (2008) Tracing the impact of bank liquidity shocks: evidence from an emerging market. Am Econ Rev 98(4):1413-1442

Peek J, Rosengreen E (1995) Bank lending and the transmission of monetary policy. In: Peek J, Rosengren E (eds) Is bank lending important for the transmission of monetary policy. Federal Reserve Bank of Boston

Puri M, Rocholl J, Steffen S (2011) Global retail lending in the aftermath of the us financial crisis: distinguishing between supply and demand effects. J Financ Econ 100(3):556-578

Santos J (2011) Bank corporate loan pricing following the subprime crisis. Rev Financ Stud 24(6):19161943

Van den Heuvel S (2001) The bank capital channel of monetary policy. University of Pennsylvania, Wharton School, mimeo

Van den Heuvel S (2002) Does bank capital matter for monetary transmission? Fed Reserve Bank N Y Econ Policy Rev 8:259-265

Watanabe W (2007) Prudential regulation and the 'credit crunch': evidence from Japan. J Money Credit Bank 39(2-3):639-665

Woo D (2003) In search for 'capital crunch': supply factors behind the credit slowdown in Japan. J Money Credit Bank 35(6):1019-1038 